\title{
Regional Cooperation in South Asia
}

\author{
Papia Guha \\ College of William \& Mary - Arts \& Sciences
}

Follow this and additional works at: https://scholarworks.wm.edu/etd

Part of the Political Science Commons, and the South and Southeast Asian Languages and Societies Commons

\section{Recommended Citation}

Guha, Papia, "Regional Cooperation in South Asia" (1991). Dissertations, Theses, and Masters Projects. Paper 1539625686.

https://dx.doi.org/doi:10.21220/s2-1gkz-rs37

This Thesis is brought to you for free and open access by the Theses, Dissertations, \& Master Projects at W\&M ScholarWorks. It has been accepted for inclusion in Dissertations, Theses, and Masters Projects by an authorized administrator of W\&M ScholarWorks. For more information, please contact scholarworks@wm.edu. 
REGIONAL COOPERATION IN SOUTH ASIA

A Thesis

Presented to

The Faculty of the Department of Government

The College of William and Mary in Virginia

\author{
In Partial Fulfillment \\ of the Requirements for the Degree of \\ Master of Arts
}

by

Papia Guha

1991 


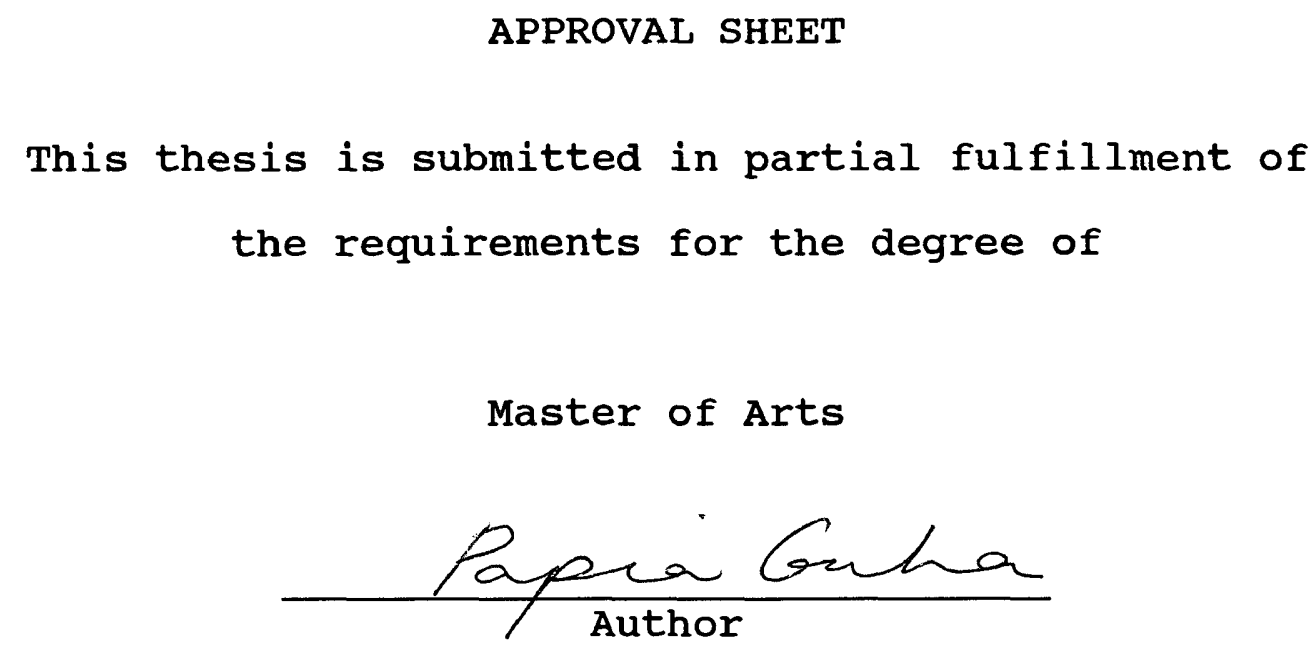

Approved, May 1991
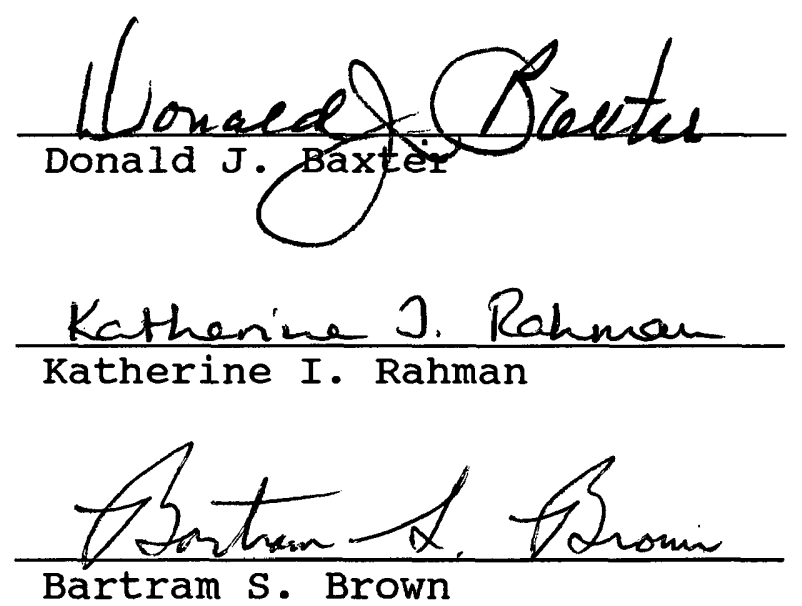
Dedicated to my family for all the love and support throughout the years. 


\title{
TABLE OF CONTENTS
}




\section{ACKNOWLEDGEMENTS}

The author wishes to express her sincere appreciation to Professor Donald Baxter, under whose supervision this thesis was written, for his patient guidance and thoughtful criticism. The author is indebted to Professors Katherine Rahman and Bartram Brown for their careful reading and valuable criticism of the manuscript. The author would also like to thank all her friends in williamsburg, especially Mrs. Barbara Wright, for their unwavering support and encouragement throughout the course of the entire program. 


\section{ABSTRACT}

The study of regional integration has become an essential topic of research in modern International Relations. Regional cooperation is the fundamental step leading towards regional integration. This thesis, using the South Asian Association for Regional Cooperation (SAARC), as the case study, argues that political cooperation through elite rapport is a pre-condition for the success of regional cooperation. The South Asian case demonstrates that fruitful regional cooperation depends upon the presence of elite rapport. 
REGIONAL COOPERATION IN SOUTH ASIA 


\section{INTRODUCTION}

South Asia, cut off from the rest of the Asian landmass by the Himalayan, Karakoram, Sulaiman and the Hindukush mountain ranges, constitutes a distinctive geographic region. The countries of this region share common historical, cultural and linguistic ties. The common heritage of colonial rule continues to shape South Asian politics.

Modern South Asia faces what at the surface seems to be insurmountable challenges rising from rampant poverty, rapidly growing populations, unemployment and low economic growth which are compounded by the presence of domestic conflicts rising primarily from secessionist movements. The South Asian region accounts for nearly 20 percent of the world's population occupying only 3.3 percent of the earth's surface area. ${ }^{1}$

In December 1985, the leaders of seven South Asian states convened for an unprecedented Summit at Dhaka, where they unanimously adopted a Charter for regional cooperation

${ }^{1}$ Nirijan M.Khilnani, "India's Political and Economic Policies Towards Her Neighbors," Round Table 301 (January 1987) : 53 . 
in South Asia. After nearly five years of discussion and debate at the bureaucratic level, the leaders of Bangladesh, Bhutan, India, Maldives, Nepal, Pakistan and Sri Lanka formally launched the South Asian Association for Regional Cooperation (SAARC), to promote cooperation to accelerate the development of the South Asian region. The birth of the SAARC gave rise to hopes that this organization would ultimately attenuate regional friction in South Asia, as well as promote development.

The increasing awareness of the interdependence of states has led to the development of the concept of regional cooperation and the creation of a number of regional organizations in different parts of the world. Most states of the world have realized the importance of cooperation with other states in similar conditions in a particular area. $^{2}$ The formation of the European Community (EC) popularized the concept of regional economic cooperation. This growing faith in regionalism was further vitalized by the growth of a number of regional bodies like the Latin American Free Trade Association (LAFTA) and the organization of African Unity (OAU). In Asia, the relative success of the Association of South-East Asian Nations (ASEAN) and the Gulf Cooperation council (GCC) acted as catalysts in the efforts to promote cooperation among the South Asian

\footnotetext{
${ }^{2}$ Atiur Rahman, Political Economy of SARC (Dhaka: University Press Ltd., 1985), 4-5.
} 
states.

South Asia, the region of intermittent border conflict, internal tensions and dubious bilateral relations since the end of colonial rule, had long been the only region in the world without a "rudimentary regional organization."3 The formation of the SAARC in 1985, raised hopes, especially among the regional intellectuals that this institution would help to resolve the longstanding, bitter regional disputes in South Asia. However, the SAARC has not been able to live up to these high expectations.

The SAARC at present is following the guidelines of the functionalist methods of regional integration. ${ }^{4}$ The principle belief underlying the functionalist approach adopted by the SAARC is that cooperation in economic and other so-called apolitical fields will promote cooperation among the member states and create a suitable atmosphere for the solution of the long-standing political conflicts within the region. No provision has been made for the discussion of political disputes, which for all practical purpose, have been excluded from the scope of the SAARC. Collective selfreliance of the region at large based on the promotion of mutual trust, amity and peaceful coexistence is the primary

${ }^{3}$ Imtiaz Bokhari, "South Asian Regional Cooperation: Progress, Problem, Potential and Prospects," Asian Survey Vol. 25, No. 4 (April 1985): 371 citing Bharat Wariavwala, "Timid Search for Status," Seminar No. 256 (December 1980): 22 .

${ }^{4}$ See SAARC Charter (Appendix A). 
objective of the SAARC.

However, the present political discord in the region makes the concept of regional cooperation for economic development more an idealistic concept than a feasible one. In most third world states, and especially among the south Asian states, politics reigns supreme over economics. It seems to be the former that molds the latter. In South Asia, the process of nation-building continues and socioeconomic forces remain comparatively underdeveloped. Hence, political forces, nationality, sovereignty and strategic considerations, continue to be the primary forces guiding the destiny of the seven SAARC members.

Partha S. Ghosh argues that an indispensable element of regional cooperation is mutual rapport among elites of the states, which is practically absent in South Asia. ${ }^{5}$ The all-important presence of a "political will" which is imperative for the formation of regional cooperation is totally lacking among the SAARC members. ${ }^{6}$ what is very visible is the political discord and turmoil, with the antagonistic Indo-Pakistani relations being the centerpiece. The political tension in South Asia is augmented by the

${ }^{5}$ Partha S. Ghosh, Cooperation and Conflict in South Asia (New Delhi: Manohar Publications, 1989); vii.

${ }^{6}$ Rajiv Kumar, "International Economy and Its Impact on the Asian-Pacific Region," in V.D.Chopra, M.Rasgotra and K.P. Mishra, eds., Asia-Pacific: Economic Potentials and Prospects (New Delhi: Continental Publishing House, 1988), 74. 
acute fear of Indian hegemony which continues to influence the actions of the other SAARC members.

In essence, regional cooperation in South Asia has to be politically motivated. If SAARC is to succeed, the "contentious bilateral issues" which have been excluded from the scope of the Charter must be addressed. It seems quite impossible to expect the SAARC members to cooperate with one another while these disputes continue to exist. These disputed issues, supplemented by the lack of understanding among the regional elites, continue to mar the development of cooperation within South Asia.

This thesis consists of four chapters. The first chapter lays out the theoretical framework for regional cooperation in South Asia, including the main argument of this thesis, that successful regional cooperation depends on political cooperation. Political cooperation, in turn, has been elusive in South Asia, mainly due to the absence of elite rapport stemming from the congruence of political beliefs and common threat perceptions.

The second chapter provides a brief history of the evolution of regional cooperation in the South Asian region, highlighting both the intra-regional and extra-regional factors which impeded the development of a regional body for a considerable period of time. The chapter illustrates that divergent political beliefs and the absence of common threat perceptions retarded the development of regional cooperation 
in South Asia.

The third chapter, analyzing the inherent

characteristics of the South Asian region, focusses on the different political and economic obstacles which have obstructed the progress of SAARC, and demonstrates the direct relationship between the preponderance of bilateral political conflicts and elite cooperation.

The fourth chapter reviews the proceedings of the five SAARC Summits. Focussing on the correlation between elite rapport and the level of success or failure of the summits, this chapter, reveals the political character of these meetings. Power politics and strategic manouvering between India and Pakistan have been the principle feature of the Summits held so far.

The conclusion will once again reiterate the fundamental theme of this thesis, which is supported by the brief history of the SAARC: Elite rapport, a product of shared political values and common perception of threats, is a pre-condition of the political harmony necessary for successful regional cooperation. 
CHAPTER 1

REGIONAL COOPERATION IN SOUTH ASIA: A THEORETICAL FRAMEWORK

Theories of regional integration have become an integral part of the study of modern international relations. ${ }^{1}$ Regional cooperation is one of the primary steps leading to regional integration. This thesis puts forward the proposition that political cooperation, stemming from rapport among regional elites, is a pre-condition for the success of regional cooperation. Two elements promoting elite rapport are congruence in political beliefs and common threat perceptions. Contradicting the functional theory of integration, which emphasizes the importance of socioeconomic cooperation, this thesis will illustrate that at the formative stage of any organization promoting regional cooperation, political cooperation must precede economic cooperation rather than the reverse. The organization under consideration in this thesis is the South Asian Association for Regional Cooperation (SAARC). This chapter lays out the theoretical framework of the thesis.

${ }^{1}$ Theories of regional integration like federalism and functionalism have become essential components of any study of modern international relations. 
THE SOUTH ASIAN REGION

At the outset, it is imperative that we define the term "region" and discuss whether South Asia can be considered a region. A region may be defined as "a particular geographic area of the world, the constituent states of which have shared historical, cultural and economic features and which in foreign affairs behave as interrelated units."2 Cantori and spiegel, in their study of the subsystems of the world, identified the South Asian region as a valid subsystem of states. They defined the South Asian region comprising India, which forms what Cantori and spiegel call the core sector, and Pakistan, Bhutan, Nepal, Sikkim, Sri Lanka, Maldives, Afghanistan and Burma, which they call the peripheral sector. ${ }^{3}$

The South Asian Association for Regional Cooperation (SAARC) consists of all these states except sikkim, Afghanistan and Burma. The only additional member is Bangladesh which emerged from the former province of East Pakistan in 1971. Sikkim was incorporated as a state into the Indian Union in 1975. The founders of the SAARC overlooked Burma, as it has always maintained an

2Partha S. Ghosh, Cooperation and Conflict in south Asia (New Delhi: Manohar Publications, 1989); 7.

${ }^{3}$ Louis J. Cantori and Steven L. Spiegel, "The International Relations of Regions," in Richard A. Falk and Saul H. Mendlowitz, eds., Regional Politics and World Order (San Francisco: W.H. Freeman and Company, 1973), 339 . 
isolationist stance in international politics. The soviet intervention and subsequent occupation of Afghanistan in 1979, sealed its fate regarding membership of the SAARC in the formative years of the organization. However, since then the Kabul Government has shown enthusiasm over joining the SAARC and made an attempt to join the SAARC in 1987. But the SAARC members except India, rejected the Afghan bid. To summarize, geographically, historically and culturally, South Asia does indeed constitute a region, even though political disparities are great.

All the South Asian states share the same political background, i.e. the colonial past, but the post colonial state that emerged took very diverse forms. India and sri Lanka functioned as democracies. Pakistan and Bangladesh went through phases of democratic and authoritarian regimes with the military playing prominent roles in both states. Nepal which for a long time remained under the authority of the monarch, witnessed the emergence of a more democratic system in 1990. Bhutan remains a traditional monarchy while Maldives has a presidential system of Government.

\section{REGIONAL INTEGRATION AND REGIONAL COOPERATION}

The concept of integration can be defined as "forming parts into a whole or creating interdependence." 4 Ernst

${ }^{4}$ Robert J. Lieber, Theory and world Politics (Cambridge, Massachusetts: Winthrop, 1972), 38 . 
Haas, a principle exponent of regional integration theory states that:

the study of regional integration is concerned with explaining how and why states cease to be wholly sovereign, how and why they voluntarily mingle, merge, and mix with their neighbors so as to lose the factual attributes of sovereignty while acquiring new techniques for resolving conflict between themselves. Regional cooperation, organizations, systems and subsystems may help describe steps on the way. but they should not be confused with the resulting condition. ${ }^{5}$

There is a lack of consensus among scholars about the scope of integration. Amitai Etzioni regards integration as a "terminal" condition. ${ }^{6}$ Karl Deutsch, on the other hand, identifies integration as a "process leading to the creation of security communities." 7

For this study of the South Asian model for regional cooperation, Morton Kaplan's definition of the integration process seems most suitable. Kaplan defines integration as "a process by which separate systems develop a common framework which allows for the common pursuit of some goals

5Ernst B. Haas, "The Study of Regional Integration: Reflections on the Joy and Anguish of Pre-Theorizing," International organization Vol. 24, No. 4 (Autumn 1970): 610.

${ }^{6}$ Amitai Etzioni, Political Unification: A Comparative Study of Leaders and Forces (New York: Holt, Rinehart and Winston, 1965), 6 .

'Karl Deutsch, et al., eds., Political Community and the North Atlantic Area (Princeton: Princeton University Press, 1957), 70 . 
and common implementation of some policies." 8

In South Asia, the SAARC provides the framework for the implementation of policies intended for the development of some goals. The SAARC Charter states that the goal of the SAARC is the socio-economic development of the region and the promotion of peace and harmony based on mutual trust.9 Haas' definition of regional integration does not seem to fit the South Asian model primarily because the SAARC Charter clearly states that there will be no infringement whatsoever on the sovereignty of the member states. Hence, Kaplan's definition is more appropriate to explain the south Asian case.

There is considerable confusion regarding the usage of regional integration and regional cooperation and an effort should be made to avoid the use of these terms interchangeably. Haas defines regional cooperation as, "a vague term covering any interstate activity with less than universal participation designed to meet some commonly experienced need."10 The study of regional cooperation provides the data on the activities or beliefs of the principle groups involved, while the study of regional integration is more concerned with the "outcomes or

\footnotetext{
${ }^{8}$ Morton Kaplan, System and Process in International Politics (New York: John Wiley \& Sons, 1957), 98.

${ }^{9}$ See Appendix A.

${ }^{10}$ Haas, 611 .
} 
consequences of these activities for the region in question". 11 Regional cooperation can be studied either as a part of regional integration or as a separate subject of its own. Regional cooperation maybe regarded as the means to the end, the end being regional integration. This thesis will use the term regional cooperation when discussing the SAARC, appropriate to its present state of development.

\section{THEORIES OF REGIONAL INTEGRATION}

There are numerous theories and interpretations of regional integration. This portion of the chapter will concentrate on reviewing four traditional theories of regional integration. These are: federalism, functionalism, neo-functionalism and communications theory.

Federalism constitutes the political and legal approach to integration. K.C. Wheare defines federation as an association of states which has been formed for certain common purposes, but in which the member states retain a large measure of their original independence. ${ }^{12}$ Federal theorists like Carl J. Friedrich, K.C. Wheare argued that the establishment of common institutions facilitate the "growth of common attitudes and a sense of community."13

${ }^{11}$ Ibid.

${ }^{12}$ K.C. Wheare, Federal Government (London: oxford University Press, 1953), 1.

${ }^{13}$ Lieber, 39. 
Federalists propagate the uniting of a set of political communities in a common order with limited infringement on their autonomous status. ${ }^{14}$ They are concerned with the constitutional approach advocating the formulation of written constitutions specifying the division of powers among the various constituent units.

Functionalism emphasizes the preeminence of socioeconomic factors over the political factors in forging regional cooperation. Functionalism "attempts to identify common international economic and social problems and create regional or global organizations to deal with them."15 This would lead to a "conglomeration of border-crossing organizations" which would ultimately control every facet of the socio-economic life. ${ }^{16}$ The underlying belief is that the establishment of socio-economic ties, it would lead to the solution of other problems as well. The emphasis is on the "spill-over" effect. Functionalism would "overlay political divisions with a spreading web of international activities and agencies, in which and through which the interests and life of all the nations would gradually be

\footnotetext{
${ }^{14}$ Ibid.
}

${ }^{15}$ Charles A.Duffy and Werner J. Feld, "Wither Regional Integration Theory?" in Werner J. Feld and Gavin Boyd, ed. Comparative Regional systems: West and East Europe, North America, The Middle East and Developing Countries (New York: Pergamon Press, 1980), 500 .

${ }^{16}$ Ibid. 
integrated."17 The essence of functionalism is that stepby-step economic decisions are superior to crucial political choices. ${ }^{18}$

Neo-functionalism developed primarily out of the criticism of functionalist theory. Neo-functionalist theory evolved in the 1950s with the implementation of the Schuman Plan which led to the formation of the European Coal and Steel Community. ${ }^{19}$ Ernst Haas' writings form the core of neo-functionalist literature. Haas put forward the proposition that as "pressure groups begin to organize across national boundaries in order to be able to influence policy decisions that were once the monopoly of national Governments, but that now come under the purview of supranational institutions, group pressures spill over into the federal sphere and thereby add to their integrative impulse." 20

The neo-functionalists, unlike the functionalists, recognize the role of the political actor in the integration process. Haas defines neo-functionalism as the process whereby political actors "shift their loyalties,

${ }^{17}$ David Mitrany, A Working Peace System (London: Royal Institute of International Affairs, 1946) 14.

${ }^{18}$ Lieber, 42 .

${ }^{19}$ A.P.Rana, "Regionalism As An Approach to International order: A Conceptual overview," International studies Vol. 18, No. 4 (October-December 1979): 523 .

${ }^{20}$ Ernst B. Haas, The Uniting of Europe (Stanford, California: Stanford University Press, 1958), xxxiii. 
expectations or political activities towards a new and larger center, whose institutions possess or demand jurisdiction over the pre-existing national states." 21

Karl Deutsch's communications approach defines integration using the security community approach. He believes that integration among countries may be attained through the establishment of relationships which build strong community spirit and this sense of community will prevent future warfare among the states. ${ }^{22}$ Deutsch divided the communities formed into two categories. The amalgamated community, where all the independent units formed a single union, and the pluralist society where the states retain their separate Governments and their legal sovereignty. ${ }^{23}$ Deutsch enumerated fourteen conditions which help in the formation of these communities. However, he stressed two indispensable conditions necessary for the formation of both amalgamated and pluralist communities: compatibility of major values and mutual responsiveness. ${ }^{24}$

According to Deutsch, compatibility of major values means, "that no value will be considered important in the relations between political units unless it is important within each of them, and is considered important in their

\footnotetext{
${ }^{21}$ Ibid. , 16.

${ }^{22}$ Deutsch, 5 .

${ }^{23}$ Ibid. , 6 .

${ }^{24}$ Ibid. , 123-129.
} 
common relations."25 Mutual responsiveness was "a matter of perpetual attention, communication, perception of needs and responsiveness. "26

The functionalist school emphasizes economic factors while Deutsch's two essential conditions for the creation of security committees are political in character.

MODERN APPROACHES TO THE STUDY OF REGIONAL INTEGRATION

The 1970s saw a revision in the study of regional integration. Ernst Haas admitted that traditional integration theories were reaching a state of obsolescence. ${ }^{27}$ He urged the revision of these theories in order to explain the modern phenomena of regionalism which were not following any of the paths predicted by the classical theories. Haas advised that the study of regional integration should be subordinated to the study of the changing patterns of interdependence. ${ }^{28}$

Modern theorists, after observing the functioning of diverse regional bodies, have come to the conclusion that certain conditions are necessary for the success of regional cooperation. Partha Ghosh argues, rather like Deutsch, that

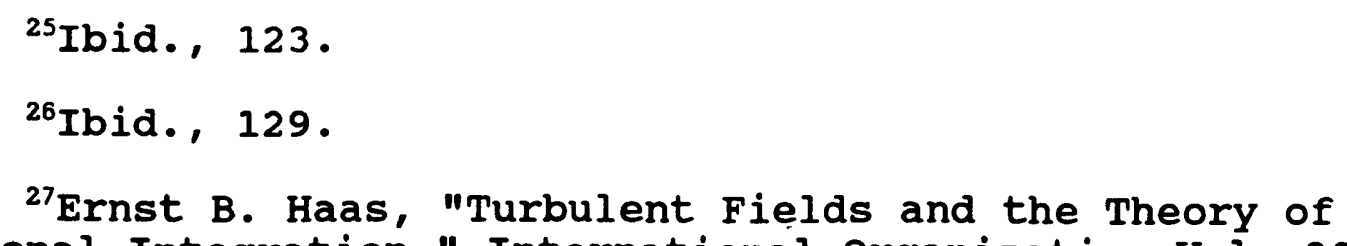
Regional Integration," International Organization Vol. 30, No. 4 (Spring 1976): 208.

$$
{ }^{28} \text { Ibid. }
$$


the essential element for regional cooperation is rapport among the regional elites. Shared security concerns and similar political perspectives form the basis for this rapport. ${ }^{29}$

Mohammed Ayoob, after studying the EC, the ASEAN and the GCC, comes to the conclusion that the indispensable factors for the success of regional cooperation are political and strategic rather than economic in nature. ${ }^{30}$ He states that in the initial stages of any regional organization promoting cooperation, political cooperation has to precede economic cooperation. Ayoob lists the factors as:

1) common and similar threats which forms a congruence in security perceptions.

2) congruence in political perceptions.

3) congruence in strategic perceptions.

4) a consensus regarding the role of the pivotal power within the regional grouping, a consensus shared by the pivotal power itself. ${ }^{31}$

Ayoob's four conditions indicate the importance of elite rapport by emphasizing the importance of congruence in security, political and strategic power perceptions.

This emphasis on elite cooperation by both Ghosh and

${ }^{29}$ Ghosh, vii.

${ }^{30}$ Mohammed Ayoob, "The Primacy of the Political: South Asian Regional Cooperation (SARC) in Comparative Perspective," Asian Survey Vol. 25, No. 4 (April 1985): 445.

${ }^{31}$ Ibid. 
Ayoob may be traced back to Deutsch's security community approach which accentuated the compatibility of values and mutual responsiveness among the regional elites as crucial conditions necessary for the success of regional integration.

This emphasis on the primacy of political factors can be found in the works of many political theorists. Contradicting the traditional functionalist approach, which emphasized the importance of economic cooperation, these authors stress the necessity of political cooperation in bringing about cooperation within a region.

Jacob Viner, in his classic study on the Customs Union, argues that cooperative economic arrangements are the outcome of "political and security" considerations rather than mere economic considerations. ${ }^{32}$ The preeminence of political relations shaping the economic framework has been argued by Robert Gilpin in his work on the effects of the multinationals as independent actors in international relations. Gilpin states that, "politics determines the framework of economic activity and channels it in the directions which tend to serve the political objectives of dominant political groups and organizations". ${ }^{33}$

${ }^{32} \mathrm{Jacob}$ Viner, The Customs Union Issue (New York: Carnegie Endowment for International Peace, 1950), 92.

${ }^{33}$ Robert Gilpin, "The Politics of Transnational Economic Relations," in Ray Maghroori and Bennett Ramberg, ed., Globalism versus Realism: International Relations' Third Debate (Boulder: Westview Press Inc., 1982), 176-177. 
Constantine Vaitsos, in his analytical study of Latin

American economic integration contends that regional

cooperation "calls for a significant role to be played by

the member countries' governments and the viability of the

process is subject to a continuous commitment and

manifestation of political support." 134

These scholars clearly believe that regional economic cooperation has to be preceded by some kind of political collaboration among the regional elites. Improved elite relations are imperative for economic cooperation. Economic ties established through political cooperation, in turn, reinforce the political cooperation already established. Peter G. Peterson comments that, "improvement in political relationships is a pre-requisite for improved economic relationships, but once in place, economic ties create a community of interests which in turn improve the environment for further progress on the political side."35

\section{CONCLUSION}

South Asia constitutes a viable region of the world, for the purposes of this analysis. Classical integration theorists have endeavored to explain the growth of regional

${ }^{34}$ Constantine Vaitsos, "Crisis in Regional Economic Cooperation (Integration) Among Developing Countries: A Survey," World Development Vol. 6 (June 1978): 719.

${ }^{35}$ Peter G. Peterson, US-Soviet Commercial Relations in a New Era (Washington D.C.: Department of Commerce, 1972), 3 . 
organizations. However, they have not been able to account for the success or failure of these cooperative bodies. At present more interest has been shown in the study of regional cooperation rather than that of regional integration.

Karl Deutsch, Partha Ghosh and Mohammed Ayoob have emphasized that for the success of regional cooperation, certain pre-conditions are necessary. Propounding the preeminence of political cooperation, they state that elite cooperation is the primary pre-condition for the successful operation of any scheme of regional cooperation. This elite cooperation stems from the presence of congruent political perspectives and from common threat perceptions. Hence, for regional cooperation to succeed, political and strategic cooperation has to usher in economic cooperation and not the reverse.

The proposition put forward in this thesis is that political (including strategic) cooperation must precede economic cooperation for the successful implementation of any scheme of regional cooperation. Political cooperation depends on cooperation and understanding among the regional elites. Using the SAARC as a case study, the following chapters of this thesis will argue that the rise and fall of regional cooperation in South Asia can be explained by the presence or absence of elite rapport and political cooperation. 


\section{CHAPTER 2}

EVOLUTION OF REGIONAL COOPERATION IN SOUTH ASIA

The South Asian Association for Regional Cooperation (SAARC) was inaugurated in 1985. It has endeavored to promote regional cooperation in the conflict-ridden south Asian sub-continent. The roots of this movement for regional cooperation can be traced back a long way. Several abortive attempts by Nehru and other statesmen preceded the final successful scheme proposed by President ziaur Rahman of Bangladesh in 1980. Tracing the evolution of regional cooperation in South Asia, this chapter illustrates that the lack of rapport among the regional elite, stemming from the absence of corresponding political perspectives and common strategic perceptions, delayed regional cooperation in South Asia.

\section{EARLY ATTEMPTS}

The history of regional cooperation in South Asia can be traced to ancient times. Neither man nor a state can survive in absolute isolation. The necessity for self 
preservation promotes interrelations. ${ }^{1}$ States often "cooperated" with one another in order to attain some common goal. These early ventures were strategic in nature, with rulers of different kingdoms and principalities forming alliances to either ward off foreign invasions or to fight amongst themselves to preserve territorial integrity.

The ancient epic, the Mahabharata, provides a vivid account of the battle (estimated to have taken place around 1000-700B.C.) between two Aryan tribes. The Kauravas and the Pandavas formed extensive alliances with other tribes to establish their control over the northern parts of the subcontinent. ${ }^{2}$ In 327 B.C., King Porous tried unsuccessfully to unite the local princes in order to prevent Alexander's invasion of the north-western parts of the Indian subcontinent. ${ }^{3}$

Later on, time and again, the Rajput princes and other Hindu rulers endeavored to put aside differences and cooperate with one another to stem the Muslim invasion of India. In 1191 A.D., Rajput princes rallied under the leadership of Prithvi Raj Chauhan to defeat the Muslim

1T.B. Mukherjee, Inter-state Relations in Ancient India (Meerut: Meenakshi Prakashan, 1967), 46.

${ }^{2}$ Romila Thapar, A History of India: Volume I (Baltimore: Penguin Books, 1966), 31.

${ }^{3} \mathrm{~J}$. Allan, Sir T.Wooseley Haig and H.H. Dodson, The Cambridge Shorter History of India (New York: The Macmillan Company, 1934), 24 . 
conqueror, Muhammed Ghori. ${ }^{4}$ From the sixteenth century onwards, with the conquest of South Asia by the European powers, most of these cooperative alliances aimed at ending foreign rule and re-establishing indigenous regimes.

In the twentieth century, the earliest call for Asian regionalism came from the Japanese who raised the slogan, "Asia for the Asians." However, the Japanese invasion of Southeast Asia proved that this call was motivated more by imperial ambition rather than any idealistic plans of regional cooperation.

on the sub-continent, leaders of the Indian Independence movement supported this concept of pan-Asian regionalism enthusiastically, especially to end colonial rule in the continent. Many Indian leaders reiterated this idea of forming an Asian Federation. ${ }^{6}$ In August 1945, Jawaharlal Nehru stated, "I stand for a South Asian Federation of India, Iran, Iraq, Afghanistan and Burma."7 Nehru and other leaders of the Indian National Congress believed that cooperation with the neighboring countries would be a critical element in the preservation of India's

\section{"Thapar, 236.}

5S.D. Muni and Anuradha Muni, Regional Cooperation in South Asia (New Delhi: National Publishing House, 1984), 10.

${ }^{6}$ Ibid.

'Ibid., citing, J.S. Bright, ed., Before and After Independence: Collection of Nehru's Speeches 1922-1950 (New Delhi, 1950). 
security interests and for the socio-economic development of the country. ${ }^{8}$

British rule on the Indian sub-continent ended in 1947. The British left behind not one but two states within the sub-continent using the religion-based "two nation theory" to divide pre-Independent India. The Islamic state of Pakistan was created from parts of British India. Partition and the emergence of Pakistan created two hostile forces on the sub-continent. Both India and Pakistan sought the help of extra-regional powers to help maintain the equilibrium within the region. Pakistan, fearing re-absorption within Hindu India's rule, actively sought alliances with the Islamic states in West Asia and other Western powers. India turned, at various times, to both the Soviet Union and the United states when her security interests were threatened. The post-Second World war period saw the formation of a number of cooperative bodies in Europe, as strategic alliances paved the way for economic cooperation among the European states. The war-devastated European countries realized that mutual cooperation would not only be of strategic importance but would also help in the economic recovery of the region. Inspired by the European efforts at regional cooperation, Jawaharlal Nehru, the first Prime

${ }^{8}$ S.D. Muni, "India's Political Preference in South Asia: A Study in India's Responses to Systematic Changes in the Region," India Quarterly Vol. 31, No. 1 (January-March 1976): 23 . 
Minister of independent India, attempted to popularize the concept of regional cooperation in the South Asian region which at that period included not only the sub-continent but also Southeast Asia. Nehru's vision of Asia included both the political and economic integration of the region.9

From 1950 onwards, several conferences were held by both South and Southeast Asian states for the promotion of economic and technological cooperation. These included the Asian Relations Conference in New Delhi in 1947, the Colombo Powers Conference in 1954 and the Bandung Conference of Afro-Asian states in 1955. These conferences proved to be mere fora for discussions and deliberations; no concrete plans of action for cooperation evolved from them.

Nehru, a fervent supporter of regional cooperation, actively preached the benefits of cooperation among the South Asian states. In collaboration with Bandarnaike of Sri Lanka, he formed the Asian Relations Organization to promote cooperation within the region in $1947 .{ }^{10}$ Despite the lack of support from the other states of the area, Nehru continued to promote his ideas for the formation of a regional cooperative body, but lack of support finally forced him to dissolve the unofficial Asian Relations

${ }^{9}$ R.V.R. Chanderasekhara Rao, "Regional Cooperation in South Asia," Round Table 293 (January 1985): 54.

${ }^{10}$ Muni and Muni, 12, citing Sisir Gupta, India and Regional Integration in South Asia (Bombay: Asia Publishing House, 1964), 37 . 
Organization in $1957 .{ }^{11}$

A principle reason for the failure of Nehru's endeavors was the change in the political environment of the region with the advent of Cold War politics. Nehru himself charged the United States with introducing cold War politics in South Asia. ${ }^{12}$ Most of the newly independent states actively participated in the emerging alliance systems chiefly to obtain aid for the development of their economies. Cold War politics divided the Asian states into opposing camps, totally embroiled in bloc politics.

In Asia itself, Pakistan, China and other smaller powers opposed Nehru's attempts at forging regional alliances, in an attempt to thwart what they considered to be increasing Indian dominance of the region. In fact, the budding rivalry between India and China led to the cancellation of the Second Asian Relations Conference in Nanking in $1949 .{ }^{13}$

By the mid 1950s, the first wave of enthusiasm for regional cooperation had come to an end. By this time however, Southeast Asia had developed a distinct regional identity of its own shaped mainly by security

\section{${ }^{11}$ Ibid.}

${ }^{12}$ Pervaiz Iqbal Cheema, "American Policy in South Asia: Interests and Objectives, " in Stephen Cohen, ed., The Security of South Asia: American and Asian Perspectives (Urbana and Chicago: University of Illinois Press, 1987), 122.

${ }^{13}$ Muni and Muni, 15. 
considerations. ${ }^{14}$ The South Asian region, now consisting of the Indian subcontinent and other neighboring countries (Bhutan, Nepal, sri Lanka and Burma) remained merely a geographic expression.

\section{THE COLD WAR ERA}

South Asian regionalism suffered a setback in 1955 when Pakistan joined the US sponsored Central Treaty organization (CENTO) and the South-East Asian Treaty Organization (SEATO) - Pakistan with her perpetual fear of Indian expansion, joined the alliances to secure foreign help in the event of an Indian attack. ${ }^{15}$

India, on the other hand, joined the newly-emerging non-aligned movement and non-alignment soon formed the core of Indian foreign policy. The non-alignment advocated by Nehru had its roots in the concept that power politics causes war and that the pursuit of peace meant keeping free of alliances with Superpowers. ${ }^{16}$ Nehru realized that remaining non-aligned would be the best course of action for India, allowing her to obtain aid from both the blocs. ${ }^{17}$

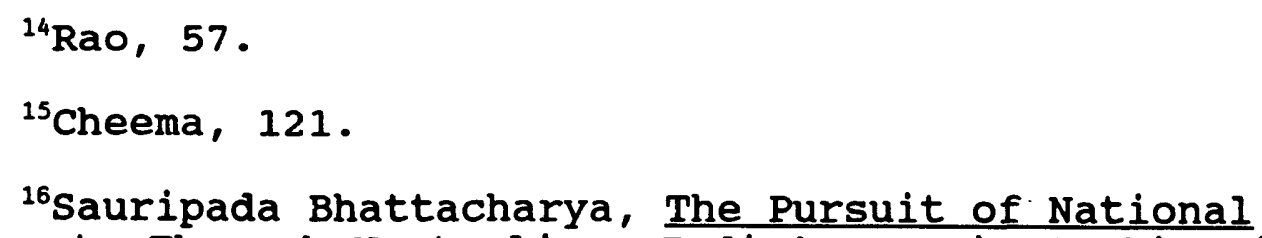

${ }^{16}$ Sauripada Bhattacharya, The Pursuit of National Interests Through Neutralism: India's Foreign Policy in the Nehru Era (Calcutta: Firma KIM Private Ltd., 1978), 5-15.

${ }^{17}$ Ahmed A Kadeer, "The Concept of Non-Alignment and Its Impact on South Asia," Pakistan Horizon Vol. 34, No. 3 $(1981): 42$. 
The Indo-Pakistani war of 1965 further reinforced this widening rift in the foreign policy orientations of the two major South Asian powers.

The late 1960s however, saw the emergence of another wave of regionalism within South Asia. ${ }^{18}$ Increased U.S. involvement in the region prompted the Soviet Union to make some efforts to promote cooperation and extend its influence within the region. ${ }^{19}$ The growing awareness in the benefits of economic cooperation was fostered by the activities of the UNCTAD and other regional commissions established by the $\mathrm{U} \cdot \mathbf{N} \cdot 20$

In the mid 1970s, the South Asian states underwent massive internal political upheavals. 1977 proved to be the year of political "upsets" in the region. In India, the newly formed Janata Party defeated the Congress Government led by Mrs. Indira Gandhi. In a major coup, General zia-ulHaq toppled the Government of Prime Minister Zulfikar Ali Bhutto in Pakistan. In Sri Lanka, President Jayawardene took over from Mrs. Bandarnaike. In Bangladesh, President Ziaur Rahman firmly established his power by 1978, filling in the vacuum created by the assassination of Sheikh Mujibar Rahman in 1975.

Economic conditions in South Asia contributed to the

\footnotetext{
${ }^{18}$ Muni and Muni, 17.

${ }^{19}$ Ibid. , 18.

${ }^{20}$ Ibid. , 19.
} 
political turmoil. Low economic growth and high population growth adversely affected the regional economy. ${ }^{21}$ The failure of the North-South negotiations, forced these states to consider once again and perhaps more seriously, the possibility of cooperating within the region to alleviate the wretched living conditions of their respective populations. ${ }^{22}$

\section{THE BANGLADESH PROPOSAL}

The final attempt at the promotion of regional cooperation was made by President Ziaur Rahman of Bangladesh. In 1979, President Rahman visited the other South Asian states and proposed his scheme for regional cooperation in South Asia. Encouraged by the responses of the other South Asian states, the Bangladeshi President formulated the Bangladesh Proposal of 1980, regarded as the genesis of the present South Asian Regional Cooperation (SARC) .

The question that rises is what motivated President ziaur Rahman to pursue this scheme for regional cooperation. There is no doubt that the soviet intervention in Afghanistan in 1979 did play a significant role in accelerating the development of regional cooperation within

\footnotetext{
${ }^{21}$ Pramod Kumar Mishra, South Asia in International
} Politics (Delhi: UDH Publishers, 1984), 79.

${ }^{22}$ Muni and Muni, 23. 
South Asia. In Bangladesh, leftist sections of the media alleged that President ziaur Rahman had been influenced by the U.S. under the Carter Administration. In fact, they accuse the Bangladesh Proposal of being a mere "echo" of the Carter Doctrine of January $1980 .{ }^{23}$

On 23 January 1980, the U.S. President Jimmy Carter in his state of the Union address, outlined the Carter Doctrine which in view of the Soviet presence in Afghanistan, emphasized the necessity of a cooperative security framework in South and South-West Asia. ${ }^{24}$ U.S. officials were sent to "persuade" the South Asian states to "evolve a regional approach" within the region. ${ }^{25}$ The Gulf Cooperation Council institutionalized regional cooperation in south-West Asia. In South Asia, President Zia issued the 1980 proposal which contained broad outlines for a scheme for regional cooperation.

President Zia's Proposal caused mixed reactions in the region. While Bhutan, Nepal, Sri Lanka and the Maldives appeared enthusiastic about the proposal of regional cooperation, the two major players of the South Asian arena, India and Pakistan, remained apprehensive. In 1980, Mrs.

${ }^{23}$ S.D. Muni, "Political Imperatives," in Bimal Prasad ed. Regional Cooperation in South Asia: Problems and Prospects (New Delhi: Vikas Publishing House; 1989), 40, citing Holiday Weekly (Dhaka) 15 June 1980.

${ }^{24}$ S.D. Muni, "SARC: Building Regionalism From Below," Asian Survey Vol. 25, No. 4 (April 1985): 394.

${ }^{25}$ Ibid. 
Gandhi returned to power in India. Her Government exhibited skepticism over accepting a scheme which they felt was covertly being sponsored by the United States. ${ }^{26}$ The Indian Government also feared that this would probably allow Pakistan and the other South Asian nations to "gang up" against India. ${ }^{27}$ on the other side, the Government of Pakistan remained apprehensive about the possible Indian domination of the organization and the benefits of economic cooperation which could very well lead to the Indian domination of the regional market. ${ }^{28}$

At the onset, despite their lukewarm reactions, neither the Indian nor the Pakistani Governments completely rejected the Bangladesh Proposal. India felt that rejection of this proposal would definitely undermine its regional policy. ${ }^{29}$ However, they sought to modify the proposal in order to accommodate their respective fears and apprehensions.

\section{PRELIMINARY STEPS TO REGIONAL COOPERATION}

As a result of the Bangladesh Proposal, a series of talks took place between the regional and the extra-regional powers. The Foreign Ministers of the concerned states met

${ }^{26}$ Ibid. , 395.

${ }^{27}$ Salamat Ali, "In ASEAN's Footsteps," Far Eastern Economic Review, 5 December 1985, 44.

${ }^{28}$ Muni, "SARC: Building Regionalism from Below," 396. ${ }^{29}$ Ibid. 
in New York in September $1980 .{ }^{30}$ They decided to hold a meeting of the Foreign secretaries to discuss the initial arrangements which would then be followed by a meeting at the Ministerial level and finally the summit sessions with the Heads of Government. The unanimous decision reached at New York was to exclude the bilateral and controversial issues from the agenda of the initial talks. ${ }^{31}$ Bangladesh assumed the responsibility of preparing the initial draft proposal for the first meeting.

Bangladesh sent its working paper on regional cooperation to the other nations in November 1980. The paper reemphasized the importance of cooperation for the economic development of the region as a whole and reiterated the hope that "a shared heritage in the region in terms of commonness in ethnicity, language, religion, history and culture would serve as a unifying factor by minimizing bilateral differences." ${ }^{32}$ The areas of cooperation proposed were telecommunications, meteorology, transport, shipping, tourism, agricultural research, joint ventures, market promotion, educational and technical cooperation and cultural cooperation. ${ }^{33}$

${ }^{30}$ Muni and Muni, 34.

${ }^{31}$ Ibid. , 35.

${ }^{32}$ Pramod Kumar Mishra, "Towards A Framework of South Asian Regional Cooperation: Colombo to Kathmandu," Foreign Affairs Report Vol. 21, No. 12 (December 1982): 214 .

${ }^{33}$ Ibid. , $216-217$. 
The first meeting of the Foreign secretaries was held in Colombo in April 1981. At this meeting, the group undertook the task of identifying the areas of cooperation. The Indian delegation expressed apprehension about discussions of bilateral political issues which might lead to the criticism of domestic policies and exert undue pressure on India. ${ }^{34}$ Their Pakistani counterpart voiced reservations about the rapid institutionalization of regional cooperation. ${ }^{35}$ The areas of cooperation agreed in Colombo included agriculture, rural development, telecommunications, weather and environmental implications, and health and population control. However, the Joint Communique issued after the meeting clearly stated that "bilateral and contentious issues" were to be excluded from the scope of these regional forums. ${ }^{36}$

study Groups were set up to investigate the five areas of cooperation. Bangladesh, India, Nepal, Pakistan and Sri Lanka had the responsibility of coordinating these groups. The Study Groups had to make definite recommendations at the next meeting to be held at Kathmandu. A Committee of the Whole, consisting of representatives of all the seven states

\footnotetext{
${ }^{34}$ Emajuddin Ahamed, SARC-Seeds of Harmony (Dhaka: University Press Ltd., 1985), 16.

${ }^{35}$ Mishra, 219.

${ }^{36}$ Ahamed, 16.
} 
was set up to consider other areas of cooperation. ${ }^{37}$

The second meeting of Foreign Secretaries, held at Kathmandu in November 1981, added four more areas of cooperation to the agenda. These included communication and transportation; sports, arts and culture; postal service; and scientific and technical cooperation. The existing study Groups were converted into working Groups and were entrusted with the task of drawing up comprehensive programs in the long and short term phases. The immediate action program would include activities such as the exchange of data and information, exchanges involving experts and training facilities, and the organization of seminars and workshops on a regional basis. The long term program of action included the assessment of needs and resources, preparation of specific projects of regional nature and the modalities for financing the projects. ${ }^{38}$

The third conference of the Foreign secretaries was held in Islamabad in August, 1982. It ended on a very positive note as the states expressed their faith in the concept of regional cooperation. The participants unanimously decided that the next meeting would be at the ministerial level. In the interim period, two meetings held

\footnotetext{
${ }^{37}$ Mishra, 220.
}

${ }^{38}$ From SARC to SAARC: Milestones in the Evolution of Regional Cooperation in South Asia (1980-1988): Vol I (Kathmandu: South Asian Association for Regional Cooperation, 1988), 23. 
in Dhaka (March 1983) and New Delhi (April 1983), formulated the guidelines to be discussed in the first meeting of the Foreign Ministers.

In August 1983, the Foreign Ministers of the seven states met at New Delhi to inaugurate the South Asian Regional Cooperation (SARC). ${ }^{39}$ Endorsing the decisions reached at the previous meetings and formulating the SARC Declaration, the member nations once again confirmed their faith in the viability of SARC. The SARC finally emerged from the conceptual stage to the pragmatic, realistic stage with definite principles and defined programs of action.

Further meetings held at the Ministerial level at Male in July 1984 and in Thimpu in May 1985 settled the framework of regional cooperation in South Asia. These preparatory stages paved the way for the first summit of the Heads of Government of the seven member states.

\section{THE FIRST SAARC SUMMIT}

In December 1985, the heads of Government of Bangladesh, Bhutan, India, Maldives, Nepal, Pakistan and Sri Lanka, met in Dhaka and adopted the Charter which formally institutionalized SARC with the formation of the South Asian Association for Regional Cooperation (SAARC). This was indeed a momentous occasion in the conflict-torn history of

${ }^{39}$ The South Asian Regional Cooperation (SARC) was institutionalized in 1985 with the formation of the South Asian Association for Regional Cooperation (SAARC). 
South Asia. The seven leaders reaffirmed their commitment to accelerate the socio-economic development of the region through mutual cooperation.

The formation of the SAARC was heralded all over south Asia. The intellectual community, in particular, showed optimism and faith about the success of the SAARC. The world-wide reaction was mixed. Though lauding the efforts of the South Asian states, there was widespread general skepticism about the efficiency and success of such a movement in a region plagued by extreme tension and illfeeling with long-standing unresolved political problems.

\section{CAUSES FOR THE SUCCESS OF THE BANGLADESH PROPOSAL}

The fundamental cause for the success of the Bangladesh Proposal (as opposed to those attempted by Nehru) lies in the fact that the 1980 proposal came from a secondary power and not either of the two major powers in South Asia. Nehru's initiatives failed mainly because the other nations, primarily Pakistan, refused to accept any plans of cooperation conceived by India, which they felt might very well be intended to disguise Indian hegemonic ambitions.

The smaller states of the region enthusiastically supported the movement. The relative success of the EC, the ASEAN and other regional bodies provided the much needed incentive to organize and promote regional cooperation. 
India and Pakistan hesitated initially, but ultimately accepted the proposals. The relations of the Congress Government of Mrs. Gandhi and the post-Mujib regimes of Bangladesh had never been very cordial. Mrs. Gandhi showed skepticism over accepting a Bangladeshi scheme of cooperation. ${ }^{40}$ Hence, the Indian reaction was very cautious. A spokesman for the Foreign office declared on 22 May 1980, that India accepted the Proposal in principle, but restricted only to economic cooperation. ${ }^{41}$ However, from 1981 onwards India changed its stance and showed greater enthusiasm for regional cooperation. India concurred in the end because she calculated that supporting the movement would build her image within the South Asian region and also raise her international prestige. ${ }^{42}$

Pakistan remained doubtful about the efficacy of this proposal for regional cooperation. A leading Pakistani daily observed that the existence of bilateral disputes and the absence of a common political purpose would restrict regional cooperation to a consultative forum. ${ }^{43}$ Pakistan

\section{${ }^{40}$ RaO, 57 .}

${ }^{41}$ M.B.Naqvi, "South Asian Cooperation," Pakistan Horizon Vol. 36, No. 3 (1983): 21 .

${ }^{42}$ Dilip Bobb, "South Asia: Sphere of Suspicion," India Today, 15 October 1983, 63 .

${ }^{43}$ Muni, "SARC: Building Regionalism from Below," 396, citing Dawn (Karachi), 29 May 1980. 
agreed after some covert persuasion by the U.S. ${ }^{44}$

President Zia's Proposal owes its success to strategic

timing and the politico-economic environment of the region

at the times.

\section{CONCLUSION}

While the rest of the world made rapid progress towards regionalism, South Asia until 1983, remained a geographic expression torn apart by bilateral conflicts augmented by distrust among the regional elites. The evolution of regional cooperation in South Asia clearly demonstrates that lack of common political perspectives and strategic perceptions slowed the development of regional cooperation within the region. Diverging political orientations of the political elites of the two major powers, India and Pakistan, alienated them from one another.

\footnotetext{
${ }^{44} \mathrm{Ali}, 44$
} 
CHAPTER 3

OBSTACLES TO REGIONAL COOPERATION: BILATERAL FRICTION

The birth of the South Asian Association for Regional Cooperation (SAARC), heralded all over the world, gave rise to hopes that this organization would ultimately reduce regional friction in South Asia. However, the progress of the SAARC has been hampered by the "contentious" bilateral relations among the states in this region. This chapter analyzes the basic characteristics shaping the political and economic environment of the South Asian region which have led to discord among the regional elites. The chapter also demonstrates that divergent political orientations have led to a multitude of political and economic problems in the region, and that these problems arise primarily in the bilateral relations between India and the other South Asian states.

\section{BASIC CHARACTERISTICS OF THE SOUTH ASIAN REGION}

The two basic characteristics of the region are 
Indocentrism and "asymmetrical power structures."1 The whole South Asian region is Indocentric in nature: geographically, culturally and to a certain extent economically. ${ }^{2}$ The Partition of British India in 1947 created the two principle states of the South Asian regionIndia and Pakistan. East Pakistan broke away from West Pakistan in 1971 and formed the state of Bangladesh. All the other states in the region have common land and maritime borders with India (but not with each other) and their old ties with British India formed the foundation of their relations with the present Indian state.

The second characteristic of the South Asian region is the asymmetrical power balance. India's superiority within the region can be discerned by comparing its "size, population, resource-base, potential for growth, military strength and viability of the constitutional and political system" with any other South Asian state. ${ }^{3}$ Consequently, South Asia must be regarded as India-dominated.

These two characteristics have led to political and economic problems. Nearly all the bilateral political disputes within the region have one common element--India. These problems, some concerning boundary issues while others

${ }^{1}$ S.D.Muni, "India and Regionalism in South Asia: A Political Perspective," International studies Vol. 17, No. 3-4 (July-December 1978): 487-488.

${ }^{2}$ Ibid.

${ }^{3}$ Ibid. , 486 . 
involving ethnic crises or the sharing of common resources, rise primarily from the Indocentric nature of the subcontinent. Within the region, the dominating presence of India is the main stumbling block to economic cooperation, as the other nations fear Indian domination of their markets and subsequently of their economies.

\section{POLITICAL PROBLEMS}

Political discord is the legacy of the years of colonial rule in this region." The genesis of the "South Asian sub-system of states," the 1947 Partition of India, generated and since then has maintained the hostile relations between the two largest countries of the region, India and Pakistan. 5 The two bi-products of this Partition are the disputed boundaries and the presence of ethnic minorities in the different South Asian states. ${ }^{6}$ Independence from colonial rule broke up the integrated regional economy and each state began to pursue independent economic policies and grew more and more alienated from

\footnotetext{
"Pramod Kumar Mishra, South Asia in International Politics (Delhi: UDH Publishers, 1984), 2 .

${ }^{5}$ Bhabani Sen Gupta, Amit Gupta and Prakash Nanda, "Regionalism in South Asia: Roles and Behavior," in Bhabani Sen Gupta ed. Regional Cooperation and Development In South Asia (Volume I): Perception, Military and Nuclear Arms (New Delhi: South Asian Publishers, 1986), 18 .

6Muni, 482 .
} 
continuing intra-regional trade.' The 1947 Partition laid the foundation of the growing mistrust among the regional elites.

Political problems in South Asia stem from the question of national integration compounded by the nation-building and developmental processes in the different states. ${ }^{8}$ The power disparities within the region are accentuated by the presence of different kinds of political structures. S.D. Muni states that cooperation is also dependent on "elite coalitions" and stresses the role of "constructive and viable coalitions of the ruling elites on the sub-continent." 9 The present political discord in South Asia may be attributed to the lack of such elite coalitions.

India is central to the region and India's contiguous boundaries with other countries lead to the dominance of bilateral rather than multilateral relations. India has common boundaries with Pakistan, Bhutan, Nepal, Bangladesh and shares maritime boundaries with Sri Lanka and Maldives. None of the other member states share common boundaries with one another. As a result, bilateralism is the principle mode of

\footnotetext{
'Mishra, 2 .

${ }^{8}$ Muni, 491.

${ }^{9}$ Ibid., 499.
} 
interaction within the sub-continent. ${ }^{10}$

\section{INDIA AND PAKISTAN}

The centerpiece of South Asian politics is the IndoPakistani relationship. The fragile balance of regional cooperation will always rest on this "hypersensitive fulcrum."11 Partition of the country based on the two nation theory which emphasized the differences between the Hindus and the Muslims, led to the creation of Pakistan in 1947. Bloody communal riots preceded the 1947 Partition of the country and led to the dislocation of thousands of people. This Partition forms the foundation of the IndoPakistani rivalry. The mutual suspicion of the Hindus and the Muslims did not recede after 1947. The creation of Pakistan on the sub-continent "transformed the intercommunal fight into an inter-state conflict."12 The fundamental justification for the existence of Pakistan, the creation of a Muslim homeland for the Muslims in the old undivided Indian state, runs directly at odds with the modern Indian emphasis on a secular state. In fact, the

${ }^{10}$ S.D.Muni and Anuradha Muni, Regional Cooperation in South Asia (New Delhi: National Publishing House, 1984), 56.

${ }^{11}$ Srinivas Prasad, "SAARC: Painful Progress," India Today, 15 December 1986, 65.

${ }^{12}$ Gowher Rizvi, "The Rivalry between India and Pakistan," in Barry Buzan and Gowher Rizvi, ed., South Asian Insecurity and the Great Powers (New York: st. Martin's Press, 1986), 96. 
hostility between the two states stem from the opposing concepts of an Islamic state and a secular state. ${ }^{13}$

Territorial conflicts between the two states have led to three wars and numerous border skirmishes since 1947. The bone of contention between the two states is the possession of Kashmir. In 1947, the Hindu Maharajah of the Muslim majority province of Kashmir, after initial hesitation, joined the Indian Union. Pakistan, on the other hand, felt that Kashmir being a Muslim dominated province, rightfully belonged to Pakistan and this liberation of Kashmir became the focal point of Pakistani domestic and international politics.

The first Indo-Pakistani War broke out in 1947 when the Maharajah of Kashmir joined the Indian Union. At the time of Partition, the different princely states were given the option of either joining India or Pakistan. The Maharajah of Kashmir, Hari Singh, remained undecided. In fact, Hari Singh harbored plans of forming his own independent state. $^{14}$ However on 22 October 1947, several hundred tribesmen from Pakistan stormed into the western part of Kashmir heading towards the capital, Srinagar. ${ }^{15}$ In desperation, the Maharajah, appealed to India for help. The

${ }^{13}$ Partha S. Ghosh, Cooperation and Conflict in South Asia (New Delhi: Manohar Publications, 1989), 18.

${ }^{14}$ Sumit Ganguly, The origins of War In South Asia (Boulder: Westview Press, 1986), 17 .

${ }^{15}$ Ibid. , 18. 
Indian Government insisted on accession to the Indian Union as a pre-condition for extending any help. The Maharajah joined the Indian Union on 27 october 1947. The very next day, Indian forces landed in Kashmir and began full scale operations against the Pakistani infiltrators. ${ }^{16}$

The war continued until U.N. mediation finally brought about a cease-fire in January 1949.17 By this time, India controlled nearly two-thirds of Jammu and Kashmir with only one-third remaining under Pakistan. ${ }^{18}$ This episode marked the beginning of the most hostile bilateral issue to plague the region. Kashmir, the picturesque valley in the Himalayas, has turned out to be a battleground between the two adversaries, India and Pakistan.

The second Indo-Pakistani war began in 1965. This was preceded by border skirmishes in the Rann of Kutch region. In response to Pakistani infiltrations into Kashmir, Indian forces crossed over the 1949 cease-fire line and launched full-scale operations against Pakistan. This war proved to be quite a setback for Pakistan. ${ }^{19}$ Indian forces penetrated beyond Kashmir and reached the outskirts of Lahore. The Tashkent Conference of 1966 followed the U.N. sponsored cease-fire. According to the Tashkent

\footnotetext{
${ }^{16}$ Ibid.

${ }^{17}$ Ibid.

${ }^{18}$ Buzan and Rizvi, 99.

${ }^{19}$ Ganguly, 89.
} 
negotiations, the Indian forces went back to their previously held positions, with the 1949 cease-fire line being reinforced.

The 1965 war led to the acceleration of the rivalry between India and Pakistan. Pakistan feared that India was trying to undermine its sovereignty and territorial integrity. This fear proved to be well-founded. In 1971, Indian and Pakistani forces clashed once again, this time in East Pakistan. The 1971 war led to the break-up of Pakistan and the creation of the independent state of Bangladesh from the old province of East Pakistan.

The Indo-Pakistani rivalry also launched an arms race between the two states. The scale tipped in India's favor after its 1974 explosion of a nuclear device. This event sparked Pakistan's fervent attempts to acquire nuclear technology to build the "Islamic Bomb."20

In the late 1980s, Kashmir re-emerged as a source of friction. Kashmiri separatists have taken up arms against the Indian government, demanding independence. They remain undecided about joining Pakistan or creating their own state. At present, Kashmir still remains a trouble-stricken area with escalated violence between the Indian troops and the Kashmiri separatists.

Allegations about overt Pakistani support for the

\footnotetext{
${ }^{20}$ Ashwini K.Ray, "Pakistan's Post-Colonial Democracy: Implications for Indo-Pakistani Relations," Economic and Political Weekly, 22 April 1989, 867.
} 
Kashmiris and the Sikh separatists in Punjab, has exacerbated Indo-Pakistani discord. Amanullah Khan, one of the leaders of the Jammu and Kashmir Liberation Front (JKLF), revealed that from 1986 onwards the Pakistani Government of General Zia-ul-Haq sponsored and operated terrorist training camps. ${ }^{21}$ Pakistan, on the other hand, has accused India of supporting the sindhi nationalist movement in Pakistan. ${ }^{22}$

Possession of the siachen glacier has led to intermittent clashes between the two nations. Both India and Pakistan claim sovereignty over this glacier. This situation deteriorated from 1984 to such an extent that it has been referred to as a "cryogenic bomb which could ignite a major war between India and Pakistan." ${ }^{23}$ The territorial dispute in the siachen is based on divergent interpretation of the watershed principle as a guideline for demarcating boundaries in mountainous regions. Pakistan opposes the Indian occupation of the Saltoro ridge in the siachen. ${ }^{24}$ Clashes in 1987 led to prolonged skirmishes between the armed forces at siachen and aroused belligerent sentiments

${ }^{21}$ A.G. Noorani, "The Kashmir Question," India Today, 30 June 1990, 61 .

${ }^{22}$ William L.Richter, "Mrs. Gandhi"s Neighborhood: Indian Foreign Policy Toward Neighboring Countries," Journal of Asian and African Studies Vol. 22, No. 3-4 (1987): 251.

${ }^{23}$ Raminder Singh, "Breaking the Ice," India Today, 15 July 1989, 79 .

${ }^{24}$ Ibid: 
in both nations. ${ }^{25}$

Indo-Pakistani relations have become a crucial issue in the internal politics of the two countries. Compromising on Kashmir means political suicide for the politicians of both nations. Benazir Bhutto initially endeavored to harmonize the relations with India. Opposition parties accused her of bending to Indian pressures. Nawaz Sharif, the present Prime Minister, accused Benazir of having accepted "India's supremacy."26 In a sincere bid to garner political support, Benazir reversed her earlier position and played the "Kashmir card" quite effectively. ${ }^{27}$ A "Kashmir policy" is a must for all electoral campaigns. Mir Ghous Bux Bizengo, a Pakistani politician states that in Pakistan, "India-baiting still commands both votes and support." 28

In India too, Kashmir has become an integral part of the domestic political arena. ${ }^{29}$ "Nothing unites the Indians more than the determination to hold Kashmir." 30

${ }^{25}$ Salamat Ali, "Smoothed-Over summit," Far East Economic Review, 19 November $1987,41$.

${ }^{26}$ Shekhar Gupta, "Benazir's Acid Test," India Today, 15 July 1989, 76 .

${ }^{27}$ Shekhar Gupta and Mushahid Hussain, "Benazir Under siege," India Today, 31 August 1990, 15.

${ }^{28}$ Shekhar Gupta, "Fourth SAARC Summit: Coming of Age," India Today, 31 January $1989,26$.

${ }^{29}$ Madhu Jain, "Turning Bitter," India Today, 15 February 1990 , 11 .

${ }^{30}$ James Clad, "India: A World at War with Itself," The Washington Post, 31 March 1991, B3. 
Hence, no political party can hope to survive by espousing independence for Kashmir. This desire to hold on to Kashmir stems from the belief that to let Kashmir go would lead to the Balkanization of the Indian state. ${ }^{31}$

Political problems have affected economic relations between the two states as well. Government restrictions are imposed on the movement of goods and people between the two nations. Each state has spent a major portion of its GNP stockpiling weapons to ward off aggressions from the other. In 1988-89, the Pakistan defence budget was 27.6 percent of its GNP $(\$ 2,240$ million $) .32$ Across the border, the Indian Government allotted 12.1 percent $(\$ 9,980$ million $)$ of its GNP to the defence sector. ${ }^{33}$

This highly sensitive and often explosive relationship between India and Pakistan, a legacy of the colonial past continues to be the key issue hampering the development of regional cooperation in the South Asian region.

\section{INDIA AND BANGLADESH}

After the 1971 war, Bangladesh maintained excellent relations with India. Indian support for the liberation of Bangladesh was appreciated and Indian patronage was sought

\section{${ }^{31}$ Ganguly, 45.}

${ }^{32}$ Thomas J. Timmons, ed and comp., U.S. and Asia Statistical Handbook (Washington D.C.: Heritage Foundation, 1989), 63 .

${ }^{33}$ Ibid. , 35. 
by Bangladesh. Sheikh Mujibar Rahman, the Bangladeshi leader, maintained close ties with India. From 1975 onwards, public discontent with sheikh Mujib's corrupt administration translated into the development of antiIndian sentiments and discomfort with the "yoke" of Indian patronage. ${ }^{34}$

The deterioration of Indo-Bangladesh relations may be attributed to the Ganges water dispute, the south TalpattyNew Moore Island conflict and the illegal immigration of Bangladeshi nationals to India.

The long-standing dispute between India and Bangladesh over the sharing of the Ganges water intensified with the completion of the Farrakka barrage in 1975, in the Indian state of West Bengal. This barrage diverted nearly 40,000 cubic meters of water per second through a link canal to prevent the silting of the River Hoogly and the Calcutta port. ${ }^{35}$ Bangladesh objected to this diversion of Ganges water on the ground that it would jeopardize the navigation and irrigation systems of Bangladesh and harm the cultivation of crops.

Bangladesh has proposed the construction of storage dams at the main tributaries of the Ganges in the IndoNepalese borders and the inclusion of Nepal to the sharing

\footnotetext{
${ }^{34}$ Richter, 253.

${ }^{35}$ Ghosh, 86 .
} 
of Ganges water scheme. ${ }^{36}$ India contends that this dispute, being strictly bilateral, should not include a third party and proposed the construction of a link canal connecting the Brahmaputra to the Ganges. Bangladesh opposed the Indian proposal, on the grounds that this would cause flooding of prime agricultural land, the dislocation of hundreds of peasant families, and would create a natural barrier between the northern provinces and the other parts of Bangladesh. ${ }^{37}$ In Bangladesh, this water dispute has been politicized and has been used to promote anti-Indian sentiments. Government statements and news editorials often resound with "anti-India tirades."38

South Talpatty island or as the Indians call it the New Moore Island, is an uninhabited island in the Bay of Bengal. Both India and Bangladesh claim ownership of the island, which was formed after a cyclone in $1970 .{ }^{39}$ This disputed claim is inter-linked to the conflict over the "delimitation of sea zones" and is compounded by the conflicting interpretations of the Law of the sea formulated in 1982.40

${ }^{36}$ M.Rafiqul Islam, "The Ganges Water Dispute: An Appraisal of a Third Party Settlement," Asian Survey Vol. 27, No. 8 (August 1987): 925.

${ }^{37}$ Ibid. .,924.

${ }^{38}$ Raminder Singh, "The Siege of Dhaka," India Today, 15 December 1987, 69 .

${ }^{39}$ Habibur Rahman, "Whose is South Talpatty Island?" Asian Profile Vol. 15, No. 5 (October 1987): 439.

${ }^{40}$ Ibid. 
This controversial question of defining maritime boundaries is also a contentious issue in Indo-Bangladesh relations. ${ }^{41}$

The influx of refugees into Calcutta gave India the pretext for entering the 1971 war. However over the years the continuous flow of illegal Bangladeshi nationals into India, especially into the state of Assam, has led to serious disputes between the two states. The Bangladeshi Government has turned a blind eye to this problem. This continuous flow of Bangladeshi nationals into Assam led to unrest among the Assamese. The fear of being reduced to minority status in their own state inspired the Assamese to agitate for the recognition of their language and claim preferential treatment for employment. ${ }^{42}$ In order to check this flow of Bangladeshi refugees into India, the Indian Government started to fence the Indo-Bangladeshi border near Assam. ${ }^{43}$ Controversy at the Governmental level of the two nations over the "barbed wire" fence even led to exchange of fire among the troops guarding the respective borders. ${ }^{44}$

Despite the looming presence of these bilateral problems, Bangladesh and India have on numerous occasions

${ }^{41}$ Ibid. , 440

${ }^{42}$ Sanjib Baruah, "Immigration, Ethnic Conflict and Political Turmoil: Assam 1979-1985," Asian Survey Vol. 26, No. 11 (November 1986): 1190.

${ }^{43}$ Ghosh, 84 .

${ }^{44}$ Ibid. , 85. 
cooperated on various issues like telecommunications, trade and even border rectifications. ${ }^{45}$ The long-standing problem over the lease of Tin Bagha region in West Bengal was resolved with the "perpetual lease" of the Tin Bagha area of India to Bangladesh. ${ }^{46}$ The disputes between India and Bangladesh, though essentially economic in nature, have become embroiled in domestic and regional politics of the region and at present pose serious obstacles to the prospects of regional cooperation.

\section{INDIA AND SRI LANKA}

The activities of the Tamil separatists in Sri Lanka led to adversial relations between India and Sri Lanka. The issue included the fate of the thousands of Tamil refugees coming into India. Some of them were the "Stateless" Indian Tamils who had been taken to Sri Lanka by the British to work as plantation workers. Large numbers of Indian Tamils were denied Sri Lankan citizenship after the independence of Sri Lanka. But most of the refugees coming to India are the Jaffna Tamils fleeing the violence of terrorist activities in the northern Tamil-dominated provinces of Sri Lanka. In the 1980s, the Liberation Tigers of Tamil Ealem (LTTE) escalated their violent activities against the sri

\footnotetext{
${ }^{45}$ Richter, 254

${ }^{46}$ P.K.S.Namboodiri, "India and Bangladesh: A New
} Beginning," Strategic Analysis Vol. 6, No. 8 (November 1982): 461 . 
Lankan Government. The violence unleashed against the ITTE in retaliation by the sri Lankan armed forces raised the sympathy of the Tamils in the Indian state of Tamil Nadu. The Government of Tamil Nadu under the rule of Chief Minister M.G. Ramchandran, extended open support and aid to the LTTE and provided a base of operation for the Tamil militants against the Sri Lankan forces. ${ }^{47}$ Influenced by the Tamils in India, the Indian Government officially sent humanitarian aid to the besieged provinces of Jaffna in $1987 .{ }^{48}$

Despite allegations and counter-accusations, the Sri Lankan and the Indian Governments signed the Indo-Sri Lankan Accord on 29 July 1987. The Accord introduced an Indian Peace-Keeping Force (IPKF) to maintain peace and stability in the Jaffna peninsula. The temporary truce in Jaffna soon gave way to a protracted struggle between the IPKF and the LTTE. Very soon, the presence of the IPKF was resented by all sections of the Sri Lankan population, as they felt that the Tamil problem was essentially an internal matter. Sri Lanka, under the Premadasa Government, brought to power by the elections of 1989, demanded the withdrawal of the IPKF

${ }^{47}$ S.U.Kodikara, "Regional Roles and Behavior in South Asia: A Theoretical Framework of Regional Cooperation," in Bhabani Sen Gupta, ed., Regional Cooperation and Development in South Asia (Vol 1): Perception, Military and Nuclear Arms Race Problem (New Delhi: South Asian Publishers, 1986), 47.

${ }^{48}$ P. Venkateshwar Rao, "Ethnic Conflict in Sri Lanka," Asian Survey Vol. 28, No. 4 (April 1988): 433. 
from Sri Lanka. The Indian government initially refused, claiming that the withdrawal would escalate the violence. Sri Lanka responded by refusing to host the 1989 SAARC Summit to protest against the presence of the IPKF. Finally, in January 1990, the IPKF withdrew from Sri Lanka but the scars of the political battles still remain. Bilateral problems between these two states affected the SAARC and increased regional apprehension about Indian "hegemony" within the region.

\section{INDIA AND NEPAL}

Nepal's relations with India have gone through both positive and negative phases. The Chinese occupation of Tibet in 1950 led to the strengthening of Nepalese ties with India. The Indo-Nepalese Treaty of Peace and Friendship extended Indian influence in Nepalese internal and external affairs. ${ }^{49}$ The fundamental basis of Indo-Nepalese relations is economic in nature. Being a land-locked state, Nepal is totally dependent on India for trade and transit. Nearly 50 percent of Nepal's trade is with India and the remaining trade overseas is done under the Transit treaty with India. ${ }^{50}$

Indo-Nepalese relations gradually deteriorated over the

${ }^{49}$ Ashraf, 16.

${ }^{50}$ N.P.Banskota, "Nepal: Towards Regional Economic Cooperation in South Asia," Asian Survey Vol. 21, No. 3 (March 1981): 344 . 
years, especially in the 1980s. India resented Nepal's seeking ties with China. India refused to endorse Nepalese King Birendra's 1973 proposal for the creation of a zone of peace. The Chinese and the Pakistani Governments promptly endorsed the peace proposal, further arousing Indian suspicion about this zone of peace. ${ }^{51}$

In 1987, Nepal for the first time required work permits for Indians working there. The Nepalese Government also imposed an extra 55 percent customs duties on imports from India. ${ }^{52}$ India protested against these actions. The Indian Government pointed out that Article 7 of the 1950 Treaty granted equal treatment for the citizens of both states. The work permits discriminated against the Indian citizens thereby violating the provisions of the 1950 Treaty. ${ }^{53}$

In 1989, Indo-Nepalese relations took a hostile turn with the lapse of the trade and transit agreement between the two states. ${ }^{54}$ The Nepalese Government refused to accept the Indian demand for a single trade and transit treaty. India retaliated by closing all but two of the

${ }^{51}$ Lok Raj Baral, "Nepal's Security Policy and South Asian Regionalism," Asian Survey Vol. 26, No. 11 (November 1986): 1207 .

${ }^{52}$ Ramindar Singh, "Towards Estrangement," India Today, 30 April 1989, 70.

${ }^{53}$ Ibid.

${ }^{54}$ Anirudha Gupta, "India-Nepal Discord," Economic And Political Weekly, 22 April 1989, 853. 
fifteen transit points on the Indo-Nepalese border leading to acute shortages of essential commodities in Nepal. 55 After considerable deliberation, enmity and adversial relations between them, the two states finally came to an agreement over the trade and transit issues. However, Nepal still remains wary about increased Indian influence over its internal and external affairs.

\section{BHUTAN AND MALDIVES}

Indo-Bhutanese relations have been very cordial primarily because Bhutan is dependent on India for its very survival. The Indo-Bhutanese Treaty of 1949 stated that Bhutanese foreign policy would be guided by India.56 India continues to provide substantial aid to the Bhutanese. However, over the years, the Bhutanese have grown to resent this dependence on India and have now established independent relations with China and several other countries. The relations with China have caused problems with India. But on the whole, Bhutan has maintained cordial relations with India and other South Asian states.

The Republic of Maldives consists of 12,000 islands in 19 groups south-west of India in the Indian Ocean. Its population is predominantly Muslim. ${ }^{57}$ Maldives has cordial

\footnotetext{
${ }^{55}$ Ibid.

${ }^{56}$ Richter, 255 .

${ }^{57}$ Ashraf, 20.
} 
relations with all other South Asian nations including India. In November 1988, a coup in the capital, Male was crushed with the help of the Indian army. ${ }^{58}$

\section{BILATERAL RELATIONS AND ELITE RAPPORT}

Partha Ghosh has cited elite rapport as a pre-condition for the success of regional cooperation. In South Asia, relationship among the regional elites have had a dramatic effect on bilateral relations. Mrs. Gandhi's aggressive foreign policy $(1966-1977)$ alienated most of the regional elite except Sheikh Mujibar Rahman of Bangladesh. During the short term of Sheikh Mujib's rule (1971-1975), IndoBangladesh relations were extremely cordial. This cordiality primarily grew out of the close personal friendship between Mrs. Gandhi and Sheikh Mujib. ${ }^{59}$

The Janata Government's (1977-1980) foreign policy, as articulateded by Foreign Minister Atal Behari Vajpayee, emphasized the necessity of improving relations with the neighbors. ${ }^{60}$ Prime Minister Morarjee Desai met Bangladeshi President ziaur Rahman in 1977 and reached a mutually acceptable agreement over the Farakka water sharing

${ }^{58}$ Madhu Jain, "An Idyllic Friendship," India Today, 15 February 1990, 41.

${ }^{59}$ Mishra, 152.

${ }^{60}$ Naveed Ahmad, "Recent Developments in Indian Foreign Policy," Pakistan Horizon Vol. 33, No. 3 (1980): 49. 
issue. 61

The Indo-Sri Lanka Accord of 1987, signed by Sri Lankan President Jayawardene and Indian Prime Minister Rajiv Gandhi, is another example of elite cooperation leading to congenial relations. However, lack of understanding between the Rajiv Gandhi and the succeeding Sri Lankan President, Premadasa, led to new friction over the presence of the IPKF .

The initial rapport between Rajiv Gandhi and Benazir Bhutto led to the success of the 1988 SAARC summit at Islamabad and Indo-Pakistani discord took a turn towards harmony. But soon, Ms. Bhutto succumbed to domestic political pressure and adopted a much harder policy towards India, especially regarding Kashmir and Siachen.

\section{ECONOMIC PROBLEMS}

A major obstacle to the growth of regional cooperation in South Asia is the wide disparity in size, population, economic resources and development between India and the other member states. India has 77 percent of the total population and 72 percent of the total land area of the region. She has 84 percent of the arable land, 69 percent of the irrigated land and nearly 90 percent of all the

\footnotetext{
${ }^{61}$ Ibid. , 70.
} 
available resources. ${ }^{62}$

Another major obstacle is the similarity of trading patterns. India and Pakistan compete in three of the four major categories of Bangladeshi exports, while India competes in eight of Pakistan's ten categories of exports. ${ }^{63}$ Import categories also reveal similarities with more than 50 percent of the imports of India, Pakistan, Sri Lanka and Bangladesh. ${ }^{64}$

Economic cooperation remains hampered by the looming presence of the comparatively large Indian economy in the South Asian region. The other SAARC members feel that unregulated trade within the region, especially with India, will hurt their newly emerging industries. ${ }^{65}$ As a result, most states have imposed trade barriers and other restrictions. In these developing nations, governmental policies regulating trade activities are interrelated to the political relations. In Pakistan, severe administrative

${ }^{62}$ M.L. Qureshi, Survey of Economic Resources and Prospects of South Asia (Colombo: Lotus Press Ltd., 1981), 7.

${ }^{63}$ Syedur Rahman, "Issues and Agenda for South Asian Regional Cooperation: A Bangladeshi Perspective," Asian Survey Vol. 25, No. 4 (April 1985): 414, quoting principle Export Commodities, External Market-1981 Statistical Yearbook (New York, 1982).

${ }^{64}$ Ibid., quoting "Imports by Broad Economic Categories," UN Yearbook of International Trade statistics (New York, 1982).

${ }^{65}$ Imtiaz H. Bokhari, "South Asian Regional Cooperation: Progress, Problem, Potential and Prospects," Asian Survey Vol. 25, No. 4 (April 1985): 386. 
restrictions curb trade with India. ${ }^{66}$ In South Asia, where the Governments control every sector of the economy either directly or indirectly through licensing and other such devices, the establishment of socio-economic ties seem impossible in the midst of political tension.

Most of the states are seriously concerned with the adverse balance of payment situation. Therefore, most of the SAARC states are reluctant to reduce trade barriers. ${ }^{67}$ The loss of extensive customs duties impedes the progress of trade liberalization in this region. ${ }^{68}$ Lack of Infrastructural linkages have affected the development of economic cooperation within the region. 69

ECONOMIC POTENTIAL

There is scope for regional cooperation in the economic sphere. One should remember that forty-four years ago, the South Asian region formed part of an integrated colonial economy. Scholars have suggested different ways in which

${ }^{66}$ Rehman Sobhan, "The Economic Background," in Bimal Prasad ed., Regional Cooperation in South Asia: Problems and Prospects (New Delhi: Vikas Publishing House, 1989), 27.

${ }^{67}$ T.P. Bhatt, "Cooperation For Economic Development," in M.S. Agwani, et al., ed., South Asia: Stability and Regional Cooperation (Chandigarh: Center for Research in Rural and Industrial Development, 1983), 38 .

${ }^{68}$ Ibid.

${ }^{69}$ Indra Nath Mukherjee, " Economic Constraints and Potentialities," in Bimal Prasad, ed., Regional Cooperation in South Asia: Problems and Prospects (New Delhi: Vikas Publishing House, 1989), 101. 
economic ties could be re-established. Principle among them are the schemes for hydro-electric cooperation between India, Nepal and Bangladesh. ${ }^{70}$

Syedur Rahman, has suggested the formation of cartels for primary commodities like tea and jute. ${ }^{71}$ These cartels would then help in price stabilization and reduce regional friction at the international markets. Other cooperative schemes include the sharing of man-power resources, the potential mineral resources of the Himalayas and in the sea-bed region surrounding the South Asian region. ${ }^{72}$

\section{CONCLUSION}

Bilateral friction in South Asia has become embroiled in the domestic politics of the individual states. The Indo-Pakistani dispute over Kashmir forms the centerpiece of South Asian bilateral friction. This conflict has led to three wars and endless number of skirmishes between the two nations. The liberation of Kashmir is the cornerstone of Pakistani foreign policy and holding on to Kashmir is

${ }^{70}$ B.G. Verghese, "River Waters: Doubts Hamper Agreements," in M.D. Dharamdasani, ed., South Asian Regional Cooperation: An Exercise in Open Diplomacy (Varanasi: Shalimar Publishing House, 1985), 159.

${ }^{71}$ Rahman, 416.

${ }^{72}$ B. Satyanarayana, "Regional Economic Cooperation for South Asian Countries," in K. Satyamurty, ed." South Asian Regional Cooperation (Hyderabad: Institute of South Asian Studies, 1982), 57-58. 
imperative to the Indian political elite. Any compromise from either side means political suicide.

The history of bilateral relations show that these relations can improve or worsen depending on the rapport among the regional elites. The 1971 Shimla Agreement between Mrs. Gandhi and Zulfikar Ali Bhutto of Pakistan ameliorated the Kashmir problem and established a line of control agreed to by both parties. But, soon this transitory rapport disappeared and Indo-Pakistani discord reemerged in full force, after the 1974 explosion of the Indian nuclear device.

The South Asian region is besieged by the presence of long-standing political and economic problems which are the results of the inherent characteristics of the region itself. Indocentrism and Indo-domination remain the two principle and intrinsic features of the South Asian region. This has led to the proliferation of bilateral problems among India and her neighbors. These bilateral problems amplified by elite discord affected and continue to affect the progress of the SAARC. 
CHAPTER 4

SAARC AT WORK: THE SAARC SUMMITS

The SAARC Charter stated that the members would hold annual summits to discuss and review the activities of the organization. The first Summit was held in Dhaka in 1985 and was followed by four other summits held in Bangalore, Kathmandu, Islamabad and Male. This chapter summarizes the proceedings of these annual summits from Dhaka to Male, highlighting the correlation between elite rapport and the relative success and failure of these summits. The chapter focusses on the discord between India and Pakistan and the effects of this relationship on the progress of regional cooperation within the region.

\section{THE DHAKA SUMMIT-1985}

The Dhaka Summit convened in December 1985 formally launched the SAARC. The Charter signed by the member states laid down the objectives of the SAARC. These objectives include the following: to promote the quality of life, accelerate economic growth and provide the opportunity to all to live in dignity; to strengthen collective selfreliance and contribute towards building mutual trust; to 
promote active collaboration in the economic, technical and scientific fields including cooperation with other developing countries and international forums with similar aims and purposes; and finally to increase people to people contacts and information between the states of the region. The principles of the Charter stated that cooperation shall be based on "respect for principles of sovereign equality, territorial integrity, political independence, non-interference in internal affairs of other states and mutual benefit."1 The Charter further stated that cooperation should not only be consistent with bilateral and multilateral agreements but should also complement them. ${ }^{2}$ Each member state had the veto power and all decisions required unanimity. ${ }^{3}$ The SAARC however, excluded all "bilateral and contentious issues" from the scope of its Charter. ${ }^{4}$ The different bodies formed to carry out the SAARC activities included the Technical committee and the Action Committee. The standing committee formed included the Foreign secretaries of the member states and had the responsibility of coordinating and monitoring the whole

${ }^{1}$ B.D. Dangol ed., SAARC Voyage From Dhaka to Bangalore (Kathmandu: Ministry of Education and Culture, Department of Archeology, 1987), 68 .

${ }^{2}$ Ibid.

${ }^{3}$ Keesing's Contemporary Archives, Vol. 32, No. 3 (March 1986), 34243 .

${ }^{4}$ Ibid. 
program of action. The financial arrangements were on a voluntary basis with each country deciding on the amount of its contribution to the SAARC. 5

The member states agreed to cooperate in different areas including transport, telecommunications, postal services, meteorology, health and family planning, agriculture and sports. 6 Apart from cooperating in specific areas, the members also recognized the need for the development of a common view on issues such as the "NorthSouth economic dialogue and the General Agreement on Tariffs and Trade(GATT) policy."7 The leaders at the summit concurred to cooperate in formulating stringent measures to counter terrorism and drug-trafficking within the region. They emphasized the necessity of frequent meetings at the ministerial and bureaucratic levels, and decided to meet at annual summits to discuss and review the progress of the organization. 8

The Dhaka Declaration, though praised as a laudatory effort to establish cooperation in South Asia, has also been subject to criticism. Even though all the seven leaders made long speeches in Dhaka proclaiming the need for 947.

${ }^{5}$ Dangol, 70.

${ }^{6}$ Facts on File, Vol. 45, No. 2352 (20 December 1985),

${ }^{7}$ Ibid.

${ }^{8}$ Ibid. 
cooperation and mutual trust, they ensured the exclusion of bilateral and contentious issues from the authority of the SAARC. Unanimous decisions and the veto power took care of the Indian fear of the domination of the organization by Pakistan and other smaller states and vice versa.

The main rationale behind the SAARC was to establish some form of economic cooperation among the South Asian states for the development of the region at large. However, trade and industry have been deliberately left out of the scope of the SAARC Charter, mainly to overcome the fear of Indian economic domination among other members. Cooperation in the trade and industrial sphere is being resisted by the other South Asian states under the apprehension that India with its relatively strong and expanding economy would dominate the regional market, adversely affecting their own developing economies. Regional cooperation in trade and industry would definitely accelerate development within the region.

The exclusion of bilateral issues from the scope of the SAARC has been controversial. It is these issues which form the main obstacles to regional cooperation in South Asia. In this region, where politics dictate the economic policy of the regional states, the future success of regional cooperation will depend on the nature of the political relations between the member countries. The King of Bhutan, His Highness, Jigme singhye Wangchuk, in his address to the 
summit explicitly stated, "In the geo-political realities of our region, it would be unrealistic to ignore the primacy of the political factor, as in the final analysis, it will be the political environment of the region that will determine the shape and scope of regional cooperation in south Asia." However, at the onset, it is the exclusion of these adverse bilateral political issues from the SAARC Charter which paved the way for the formation of the SAARC. All the member states, especially the two principle states of the region, India and Pakistan, insisted on the exclusion of these issues as a precondition to their joining the SAARC.

The Dhaka summit marked the beginning of the annual meetings of the member states. At Dhaka, India and Pakistan maintained cordial relations with another with very little dispute during the proceedings. The summit set the SAARC in motion and the members agreed to meet in Bangalore the next year.

\section{THE BANGALORE SUMMIT-1986}

Bilateral conflicts between India and Pakistan on the one hand and India and Sri Lanka on the other, overshadowed the proceedings of the second SAARC Summit at Bangalore in November 1986. The Summit opened amid reports of Indian

${ }^{9}$ Bimal Prasad, Regional Cooperation in South Asia: Problems and Prospects (New Delhi: Vikas Publishing House Pvt. Ltd., 1989), 12 . 
troop movements along the Indo-Pakistani border. In sri Lanka, Tamil militants continued their protracted struggle against the Sri Lankan armed forces. The overt sympathy and support for these Sri Lankan Tamils by their Indian counterparts seriously affected Indo-sri Lankan relations.

The Bangalore Declaration adopted by the leaders, "condemned as criminal all acts, methods and practices of terrorism."10 The Declaration stated that member countries should "refrain from organizing, instigating, assisting or participating in acts of civil strife or terrorist acts in another state and that they should not acquiesce in organized terrorist activity within their own territory."11 However, the leaders were unable to agree unanimously on the definition of terrorism. Hence, they formulated a committee which was entrusted with the task of coining a suitable definition of "terrorism" and preparing a draft proposal acceptable to all members.

The member states endorsed the proposal to establish a committee to devise cooperation for fighting the drug trafficking within the region and ratified proposals establishing a SAARC meteorological center in India and an agricultural center in Bangladesh. ${ }^{12}$ The seven leaders

${ }^{10}$ Keesing's Contemporary Archives, Vol. 32 , No. 12 (December 1986), 34815 .

${ }^{11}$ Ibid.

12"South Asia: The Spirit of SAARC," Round Table 301 (January 1987): 4 . 
agreed to evolve a joint strategy on global economic issues at international fora. ${ }^{13}$ The principle achievement of the Bangalore Summit however, was the establishment of the permanent SAARC Secretariat in Kathmandu with Bangladeshi diplomat, Abul Ahsan as the first Secretary-General.

Bilateral talks between India and Pakistan and the Indo-Sri Lankan negotiations received more publicity than the actual summit proceedings. The Pakistani delegation claimed that nearly two hundred and fifty thousand Indian troops had moved closer to the Indo-Pakistani border. The Indian spokesmen countered the Pakistani accusations by declaring this troop movement as part of the Indian army's annual winter exercises. ${ }^{14}$ India, on the other hand expressed concern over the covert Pakistani support for the Sikh separatists in Punjab. ${ }^{15}$

The Indo-Sri Lankan taiks on the Tamil issue took place under very dramatic circumstances. The Indian Government set free the Madras-based leaders of the Tamil separatists who had been placed under house-arrest before the inauguration of the Bangalore Summit. ${ }^{16}$ The Indian Prime Minister, Rajiv Gandhi, tried to negotiate a peace

${ }^{13}$ Dilip Bobb and Srinivas Prasad, "SAARC: Painful Progress," India Today, 15 December 1986, 65.

14"South Asia: Spirit of the SAARC," 4 .

${ }^{15}$ Ibid.

${ }^{16}$ Salamat Ali, "Sophistry at Summitry," Far Eastern Economic Review, 27 November 1986, 30. 
arrangement in Sri Lanka. The Indian Air Force flew in three top leaders of the Liberation Tigers of the Tamil Ealem (LTTE) to Bangalore. The Chief Minister of the Indian state of Tamil Nadu, M.G. Ramchandran arrived at Bangalore to participate in the talks. ${ }^{17}$ Prolonged negotiations took place behind close doors but the end results did not prove to be too encouraging.

The Bangalore Summit ended without any significant attempts at promoting economic cooperation. India's appeal for the inclusion of trade and industrial cooperation within the realm of the charter met strong opposition from other members especially Pakistan. ${ }^{18}$ Even though bilateral negotiations are outside the scope of the charter, the highlights of the summit included the Indo-Pakistani and Indo-sri Lankan bilateral talks. One might point out that despite the exclusion of bilateral issues from the actual SAARC agenda, these summits provide a convenient opportunity for the leaders of the region to meet annually to discuss pertinent bilateral issues. At the end of the summit it was evident that the viability of the SAARC as a regional body rested on the spirit of trust and mutual cooperation among the regional elites.

\footnotetext{
${ }^{17}$ Ibid.

${ }^{18} \mathrm{Bobb}$ and Prasad, 64.
} 
THE KATHMANDU SUMMIT-1987

The member states present at the third SAARC Summit convened in Kathmandu in November 1987 signed the Kathmandu Declaration which included a convention for the "suppression of terrorism including a provision for the extradition of convicted terrorists."19 The Declaration also endorsed the establishment of a food security reserve for combating the adverse effects of natural disasters and the commissioning of studies on natural disasters and the protection of the environment. 20

The Convention on Terrorism was the sole achievement of the third summit. This convention allowed the member states to obtain the extradition of those individuals engaged in acts of terrorism in other states or in cases where extradition was impossible, provisions formulated would facilitate quick trials. ${ }^{21}$ However, this convention contains certain loopholes, the foremost being that the decision to accept the extradition requests depended on the discretion of the states concerned with no mechanism to force compliance in accordance to the provisions of the Convention. ${ }^{22}$

${ }^{19}$ Keesing's Record of World Events, Vol. 33, No. 12 (December 1987), 35614 .

${ }^{20}$ Ibid.

${ }^{21}$ Ron Tempest, "7 South Asian Nations Vow Joint Action on Terrorists," Los Ángeles Times, 6 November 1987, 13.

${ }^{22}$ Ibid. 
As in the previous summit, the Kathmandu summit witnessed tension between the Indian and Pakistani contingents: Indo-Pakistani tension aggravated by the armed skirmishes at the siachen glacier, a month ago, reflected on the proceedings of the summit. The possession of the Siachen glacier in the north-eastern part of the IndoPakistani border has led to frequent skirmishes between the armed forces of the two states stationed in the region. The member states, apart from India and Sri Lanka, expressed concern over the Indo-Sri Lankan Accord of July 1987 and the presence of the Indian forces in Jaffna. They were apprehensive at the prospect of India assuming the role of a "regional policeman" and involving itself in the maintenance of domestic law and order of the South Asian states. ${ }^{23}$ In fact for the first time since its inception in 1985, the SAARC openly discussed a bilateral issue in the main Summit proceedings. President Jayawardene's reference to the Accord led to heated discussion of bilateral issues. Pakistan refused to endorse the Indian proposal for an official SAARC statement on Sri Lanka. ${ }^{24}$

Another controversial issue was Afghanistan's application for SAARC membership. This issue became a bone of contention between India and Pakistan. India, the sole

${ }^{23}$ Ibid.

${ }^{24}$ Salamat Ali, "Smoothed-Over Summit," Far Eastern Economic Review, 19 November $1987,39$. 
supporter of the application was opposed by other SAARC members led by Pakistan. Zain Noorani, Pakistan's Minister of State for Foreign Affairs stated that, "while there could be no objection to the admission of Afghanistan as a nation, the country being currently under soviet occupation, could hardly qualify."25 India retaliated by vetoing the Pakistani proposal to grant observer status to the ASEAN. ${ }^{26}$

Other issues causing controversies included the Bangladeshi proposal for cooperation in the development of water resources and Pakistan's proposal for a South Asian treaty banning nuclear weapons. India vetoed both proposals. On the question of economic cooperation, Mr. Noorani reiterated Pakistan's stance on the issue by pointing out that political normalization had to precede economic cooperation. ${ }^{27}$

A distinguishing feature of the Kathmandu summit was the plethora of bilateral meetings. Apart from the main Summit meeting, twenty-one mini summits were held among the seven leaders. ${ }^{28}$ once again bilateral talks received top billing compared to the summit. Kathmandu provided the ideal meeting ground for talks between the Indian Prime

\section{${ }^{25}$ Ibid.}

${ }^{26}$ Raminder Singh, "Gang up on Big Brother," India Today, 30 November $1987,33$.

${ }^{27}$ Salamat Ali, "Smoothed-over Summit," 40.

${ }^{28}$ Singh, 33 . 
Minister, Rajiv Gandhi and his Pakistani counterpart, Mohammed Khan Junejo:

The Kathmandu summit demonstrated that the success of the SAARC depended on the relations between India and Pakistan. The open hostility between these two powers marred the summit proceedings. The other members took sides depending on their respective interests and the SAARC forum witnessed a clash of wills and extensive political manouverings. Although, the other members are reluctant to admit it there is no doubt that the SAARC's future as a viable body depended on the normalization of relations between India and Pakistan.

\section{THE ISLAMABAD SUMMIT-1988}

The Islamabad summit proved to be the most successful summit held to date. This success is attributed to the cordial relations between arch rivals--India and Pakistan. The Summit allowed Indian Prime Minister, Rajiv Gandhi and the newly elected Prime Minister of Pakistan, Benazir Bhutto to meet for the first time to discuss not only SAARC issues but also negotiate on bilateral conflicts. In fact, the SAARC summit had to take a back seat to Indo-Pakistan talks. International and regional media attention was focussed on the Gandhi-Bhutto talks. A Bangladeshi diplomat even complained that the other members "were made to feel like 
part-players." 29

The Islamabad Declaration, signed on 31 December 1988, called for joint efforts to combat terrorism in the region and dedicated 1989 to fighting drug abuse and drug trafficking. ${ }^{30}$ The members also accepted the Pakistani proposal to launch the "SAARC 2000" regional plan which would include areas such as food, clothing, shelter, education and primary health. ${ }^{31}$ The members agreed to open the membership of the SAARC to all states within the region and entrusted the secretariat to come up with a suitable definition of the boundaries of "South Asia." A major achievement was the abolition of visa restrictions for the legislators and judges of member states. This privilege may later be extended to journalists, bureaucrats and others. ${ }^{32}$ The members lauded the efforts of the youth volunteer programs and the establishment of SAARC chairs, fellowships and scholarship scheme. This scheme highlights the importance of cooperation in education within the region. ${ }^{33}$ The summit participants called for an end to the

\footnotetext{
${ }^{29}$ Shekhar Gupta, "Fourth SAARC Summit: Coming of Age," India Today, 31 January 1989, 24.

${ }^{30}$ Keesing's Record of World Events, Vol. 35, No. 2 (February 1989), 36485.
}

${ }^{31}$ Salamat Ali, "A Hint of Hope," Far Eastern Economic Review, 12 January $1989,11$.

32"SAARC Summit: Islamabad Declaration," Strategic Digest Vol. 19, No. 2 (February 1989): 60 .

${ }^{33}$ Ibid. 
proliferation of nuclear weapons, both at the global and regional levels.

At Islamabad, the cordiality between India and Pakistan reflected itself in the SAARC proceedings, which went on smoothly without any protests or accusations from either side. In earlier summits the animosity between India and Pakistan had overshadowed the proceedings. This emerging amicable relationship between India and Pakistan raised hopes about the success of SAARC.

The Islamabad summit provided the opportunity for the first visit by an Indian Prime Minister to Pakistan after nearly three decades. The friendly atmosphere of the Gandhi-Bhutto talks definitely raised public expectations of future amity between India and Pakistan. Safdar Mahmood, a Lahore-based columnist summarized, "the ultimate success of the SAARC largely depends on the kind of relationship that develops between India and Pakistan." ${ }^{34}$

\section{THE MALE SUMMIT-1990}

The contentious bilateral issues between India and Sri Lanka led to the cancellation of the 1989 Summit, scheduled to be held at colombo. Sri Lanka formally declared that it would not hold the summit as long as the Indian troops

\footnotetext{
${ }^{34}$ Quoted in Gupta, 23.
} 
remained on Sri Lankan soil. ${ }^{35}$

The fifth summit was finally held in November 1990 in Male, the capital of Maldives. The summit was held amid great internal and external turmoil in most of the member states. Four of the member states--India, Pakistan, Sri Lanka and Nepal--had new governments. ${ }^{36}$ Changes in government in India and Pakistan coincided with the worsening of the Kashmir situation. This summit like other SAARC Summits provided the opportunity for talks between the two rivals.

The Male Declaration called for the extension of the SAARC activities to the core areas of "economic cooperation, biotechnology, environmental issues and tourism." 37 The leaders agreed to observe the 1990s as the "Decade of the Girl child" in accordance with the recommendations of the September 1990 world summit for Children. ${ }^{38}$ The member nations endorsed proposals to create a regional documentation center in India, a human resources development center in Pakistan and a tuberculosis treatment center in

${ }^{35}$ Keesing's Record of World Events, Vol. 36 , No. 3 (March 1990), 37357.

${ }^{36}$ Barbara Crossett, "South Asian Nations in Turmoil Will Meet," The New York Times, 21 November 1990, p A7 (L).

${ }^{37}$ Keesing's Record of World Events, Vol. 36, No. 11 (November 1990), 37857 .

${ }^{38}$ Ibid. 
Nepal. ${ }^{39}$ In the international field, members criticized the Iraqi invasion of Kuwait and called for the restoration of the Kuwaiti Government. ${ }^{40}$

The first meeting of the newly appointed Prime Ministers of India and Pakistan, Chandrasekhar and Nawaz Sharif, received maximum press coverage. The leaders met for talks at Male and agreed to hold further talks at the ministerial level in December. ${ }^{41}$ However the Male meetings of the two powers did not lead to any treaties or other formal negotiations. The Male summit went off as scheduled but without any outstanding achievement.

\section{CONCLUSION}

A review of the first five SAARC summits make one fact abundantly clear. Despite the exclusion of bilateral issues from the scope of the Charter, it is these issues that chart the difficult course of the SAARC. These bilateral relations are dependent on elite rapport. Hostile relations between India and Sri Lanka led to the postponement and finally the cancellation of the colombo summit. The relation between Indian and Pakistani elites is the

${ }^{39}$ Ibid.

${ }^{40}$ Barbara Crossett, "South Asian Leaders Call for Efforts Against Drugs," The New York Times, 25 November 1990, p 21 (L) •

${ }^{41}$ K.T.R. Menon, "Indo-Pak talks from December $18, "$ The Times of India, 23 November 1990, 7 . 
principle indicator of the success or failure of the of these summits. In Bangalore and Kathmandu, Indo-Pakistani strife reflected itself in every aspect of the proceedings whereas the close rapport between the elites of the two nations in Islamabad, led to a relatively amicable summit. The viability of the SAARC rests on the solution of bilateral political conflicts among SAARC members, especially India and Pakistan. While the SAARC Summits are often overshadowed by simultaneously held bilateral talks, one cannot deny the importance of these talks. These bilateral negotiations are extremely important and may ultimately lead to the solution of long-standing political problems. The summits provide the much-needed vehicle for the leaders to meet and communicate at regular intervals in a diplomatic atmosphere. The growing necessity and the importance of these annual summits cannot be denied. 
CONCLUSION

In 1985, the institutionalization of regional cooperation in South Asia in the form of the SAARC received accolades all over the world. The main objective of the SAARC is socio-economic development of the poverty-stricken South Asian region. Another important objective is the promotion of mutual trust among the often feuding south Asian states. However, the functioning of the SAARC over the past years has shown that it is difficult to promote socio-economic cooperation among states with long-standing political disputes reinforced by antagonistic relations among the ruling elites of the member states.

The theoretical framework laid out in the first chapter argues that at the formative stages of any organization for regional cooperation, politics will play a major role. At the onset, political cooperation is necessary to create the environment necessary for economic cooperation. Once economic cooperation is firmly established, these economic relations may prevent further political discord. Scholars like Karl Deutsch, Jacob Viner, Robert Gilpin, Constantine Vaitsos, Mohammed Ayoob and Partha Ghosh have all stressed the importance of political factors in the success or 
failure of regional cooperation. Political cooperation essentially means rapport among the regional elite. This rapport depends on similar political perspectives and common threat perceptions.

Regional cooperation in South Asia developed over a number of years. Since the end of colonial rule, regional leaders, especially Jawaharlal Nehru, espoused regional cooperation for the development of South Asia. The mistrust generated by the Partition and the advent of Cold War politics, however led to a widening of the rift among the regional elites. This elite antagonism, a result of the absence of common political and strategic perspectives, proved to be the principal barrier to development of regional cooperation in South Asia.

The success of the 1980 Bangladesh Proposal was a result of the consensus among the regional elites for the formation of a body to promote regional cooperation. However, a point to be kept in mind is that both India and Pakistan accepted this Proposal very reluctantly, though it was endorsed eagerly by Bangladesh, Bhutan, Maldives, Nepal and Sri Lanka.

The discord among the elites prevalent in South Asia is augmented by and reflected in the presence of numerous bilateral disputes. These contentious bilateral issues have made for bitter relations among the regional elites. Hence, from its very inception the SAARC has been extremely 
politicized. Different political perspectives, generated initially by Partition, are reinforced by the presence of bilateral disputes. The Indocentric nature of South Asia gives rise to the fear of Indian hegemony over the region on the part of the smaller states. This Indophobia, fortified by the existence of the various bilateral disputes, has generated mistrust among the regional elite and every Indian move (action or inaction) is viewed with suspicion.

The relationship between India and Pakistan is of primary importance. It is this relationship which holds the key to the success of the SAARC. A review of the SAARC summit proceedings reveals that the Indo-Pakistani relationship affects the success or failure of these summits directly. The summits at Bangalore (1986) and the Kathmandu (1987) suffered from the confrontations between the members of the two delegations. The Islamabad summit (1988), marked by a close rapport between the Indian and the Pakistani contingent, was the most successful SAARC summit to date. The relationship between bilateral disputes and the lack of elite harmony can be easily discerned from the study of the political relations in South Asia. Mutual

understanding and trust among the elites have been conducive for the socio-economic development within the region. The rapport between the Indian government under Mrs. Indira Gandhi and the regime of Sheikh Mujibar Rahman of Bangladesh 
is one example. Indian help in the 1971 War of Liberation in East Pakistan helped in the creation of Bangladesh. This infant nation was nurtured by India in the early years of its existence. Indo-Bangladesh cooperation extended to many fields including trade, commerce, industry and others. After the assassination of Sheikh Mujib in 1975, IndoBangladesh relations deteriorated rapidly. Mrs. Gandhi's antipathy towards the post-Mujib regimes was reflected in her apprehensions about the efficacy of the SAARC.

A more recent example of elite rapport and its effects on cooperation in South Asia can be seen in the Indo-sri Lankan relations over the Tamil issue. Initial suspicions and allegations of Indian support for the LTTE made by the Jayawardene Government soon gave way to mutual understanding leading to the signing of the Indo-Sri Lankan Accord in 1987. By 1989, however, this elite harmony had disintegrated. The Goverment of newly elected President Premadasa resented the presence of the IPKF and demanded the withdrawal of all Indian troops. This demand antagonized the Indian Government and soon a confrontational situation developed which ultimately led to the cancellation of the 1989 SAARC Summit scheduled to be held in Colombo, the capital of Sri Lanka.

In the regional relations of South Asia, the primacy of political relations over economic relations is quite apparent. The Partition of the country, tore apart the 
well-integrated economy of British India. Political and strategic considerations forced the elites of the newly created states to shun interdependence and seek to build independent economies. The complementary nature of the regional economies was deliberately severed by the elite for political reasons. At present, political discord prevents the implementation of schemes which are economically beneficial to the SAARC members. The proposed Ganges water sharing scheme between Bangladesh, India and Nepal is a good example. The hydro-power potential of such a scheme could help solve the energy crisis in the region and abate the growing dependence on foreign oil. But political concerns prevent the implementation of this hydro-power project. The reluctance exhibited by the Indian Government to accept the scheme shows that economic benefits are subordinated to political necessities.

At present, the SAARC is functioning more as a forum for diplomatic activity than as an actual body promoting cooperation. SAARC activities, burdened by regional political disputes, remain low-keyed. The future of the SAARC rests precariously on elite rapport especially on the relationship between India and Pakistan. An increase in political conflicts within the region exacerbates the prevailing mistrust and weighs down the activities and functioning of the SAARC.

The fruitful development of regional cooperation 
depends primarily on political cooperation stemming from rising levels of rapport among the regional elite as in the case of the Islamabad summit. The South Asian case study clearly shows that it is the presence or absence of understanding among the regional elites which increases or decreases the level of cooperation. The presence of a harmonious political environment encourages the development of socio-economic development within a region. Political cooperation is an indispensable pre-condition for the success of regional economic cooperation, and ultimately, regional integration. 


\section{APPENDIX A \\ CHARTER OF THE SOUTH ASIAN \\ A8SOCIATION FOR REGIONAL COOPERATION}

We, the Heads of State or Government of BANGLADESH, BHUTAN, INDIA, MALDIVES, NEPAL, PARI8TAN and BRI IANKA:

1. Desirous of promoting peace, stability, amity and progress in the region through strict adherence to the principles of the UNITED NATIONS CHARTER and NON-ALIGNMENT, particularly respect for the principles of sovereign equality, territorial integrity, national independence, nonuse of force and non-interference in the internal affairs of other states and peaceful settlement of all disputes;

2. Conscious that in an increasingly interdependent world, the objectives of peace, freedom, social justice and economic prosperity are best achieved in the 8OUTH ABIAN region by fostering mutual understanding, good neighborly relations and meaningful cooperation among the Member states which are bound by ties of history and culture;

3. Aware of the common problems, interests and aspirations of the peoples of BOUTH A8IA and the need for joint action and enhanced cooperation within their respective political and economic systems and cultural traditions;

4. Convinced that regional cooperation among the countries of SOUTH AsIA is mutually beneficial, desirable and necessary for promoting the welfare and improving the quality of life of the peoples of the region;

5. Convinced further that economic, social and technical cooperation among the countries of SOUTH AsIA would contribute significantly to national and collective selfreliance:

6. Recognising that increased cooperation, contacts and exchanges among the countries of the region will contribute to the promotion of friendship and understanding among their peoples:

7. Recalling the DECLARATION signed by their Foreign Ministers in NEW DELHI on August 2, 1983 and noting the progress achieved in regional cooperation; 
8. Reaffirming their determination to promote such cooperation within an institutional framework;

\section{DO HEREBY}

AGREE to establish an organisation to be known as so0TH ABIAN ABSOCIATION FOR REGIONAL COOPERATION hereinafter referred to as the As8OcIATION with the following objectives, principles, institutional and financial arrangements:

\section{ARTICLE I} OBJECTIVES

The objectives of the AssocIATION shall be:-

(a) to promote the welfare of the peoples of SOUTH AsIA and to improve their quality of life:

(b) to accelerate economic growth, social progress and cultural development in the region and to provide all individuals the opportunity to live in dignity and to realise their full potentials:

(c) to promote and strengthen collective self-reliance among the countries of SOUTH A8IA;

(d) to contribute to mutual trust, understanding and appreciation of one another's problems;

(e) to promote active collaboration and mutual assistance in the economic, social, cultural, technical and scientific fields:

(f) to strengthen cooperation among themselves in international forums on matters of common interests; and

(g) to cooperate with international and regional organisations with similar aims and purposes.

\section{ARTICLE II \\ PRINCIPLES}

1. Cooperation within the framework of the AssocIATION shall be based on respect for the principles of sovereign equality, territorial integrity, political independence, non-interference in the internal affairs of other states and mutual benefits.

2. Such cooperation shall not be a substitute for bilateral and multilateral obligations.

\section{ARTICLE III}

MEETING OF THE HEADS OF STATE OR GOVERMMENT

The Heads of state or Government shall meet once a year or more often as and when considered necessary by the member states.

\section{ARTICLE IV}

\section{COUNCIL OF MINISTERS}

A Council of Ministers consisting of the Foreign Ministers of the Member states shall be established with the following 
functions ;

(a) formulation of the policies of the As8OcIATION;

(b) review of the progress of cooperation under the As8OCIATION:

(c) decision on new areas of cooperation;

(d) establishment of additional mechanism under the A880CIATION as deemed necessary;

(e) decision on other matters of general interest to the A8sOCIATION.

The Council of Ministers shall meet twice a year. Extraordinary session of the Council may be held by agreement among the Member states.

\section{ARTICLE V \\ BTANDING COMMITTEE}

The standing Committee comprising the Foreign secretaries shall have the following functions;

(a) overall monitoring and coordination of programme of cooperation:

(b) approval of projects and programmes, and the modalities of their financing:

(c) determination of inter-sectoral priorities;

(d) mobilisation of regional and external resources;

(e) identification of new areas of cooperation based on appropriate studies.

The standing Committee shall meet as often as deemed necessary.

The standing Committee shall submit periodic reports to the Council of Ministers and make reference to it as and when necessary for decisions on policy matters.

\section{ARTICLE VI \\ TECHNICAL COMMITTEES}

Technical Committees comprising representatives of Member states shall be responsible for the implementation, coordination and monitoring of the programmes in their respective areas of cooperation. They shall have the following terms and reference:

(a) determination of the potential and scope of regional cooperation in agreed areas;

(b) formulation of programmes and preparation of projects;

(c) determination of financial implications of sectoral programmes:

(d) formulation of recommendations regarding apportionment costs;

(e) implementation and coordination of sectoral programmes;

(f) monitoring of progress in implementation.

The Technical Committee shall submit periodic reports to the standing committee. 
The Chairmanship of the Technical Committees shall rotate among Member states in alphabetical order every two

years.

The Technical Committees may, inter-alia, use the following mechanisms and modalities, if and when considered necessary:

(a) meetings of heads of national technical agencies;

(b) meetings of experts in specific fields:

(c) contact amongst recognised centres of excellence in the region.

\section{ARTICLE VII ACTION COMMITTEES}

The standing Committee may set up Action Committees comprising Member states concerned with the implementation of projects involving more than two but not all Member states.

\section{ARTICLE VIII}

BECRETARIAT

There shall be a secretariat of the AssocIATION.

\section{ARTICLE IX \\ FINANCIAL ARRANGEMENTS}

1) The contribution of each Member state towards financing of the activities of the Associarion shall be voluntary. 2) Each Technical Committee shall make recommendations for the apportionment of costs of implementing the programmes proposed by it.

3) In case sufficient financial resources cannot be mobilised within the region for funding activities of the AssocIATION, external financing from appropriate sources may be mobilised with the approval of or by the standing Committee.

\section{ARTICLE 8 \\ GENERAL PROVISIONB}

Decisions at all levels shall be taken on the basis of unanimity.

Bilateral and contentious issues shall be excluded from the deliberations.

IN FAITH WHEREOF We Have Set out Hands And Seals Hereunto.

DONE IN DHARA, BANGLADE8H, On This The Eighth Day of December of The Year One Thousand Nine Hundred Eighty Five. 


\section{BIBLIOGRAPHY}

\section{BOOKS}

Agwani, M.S., Ashwini K. Ray, I.N. Mukherjee, Satish Kumar and S.D. Muni. South Asia: Stability and Regional Cooperation. Chandigarh: Center for Research in Rural and Industrial Development, 1983.

Ahamed, Emajuddin. SARC-Seeds of Harmony. Dhaka: University Press Ltd., 1985.

Allan, J., Sir T. Wooseley Haig and H.H. Dodson.- The Cambridge Shorter History of India. New York: The Macmillan Company, 1934.

Bhattacharya, Sauripada. The Pursuit of National Interests Through Neutralism: India's Foreign Policy in the Nehru Era. Calcutta: Firma KLM Private Ltd., 1978.

Buzan, Barry and Gowher Rizvi, eds. South Asian Insecurity and the Great Powers. New York: St. Martin's Press, 1986.

Chopra, V.D., M. Rasgotra and K.P. Mishra, eds. AsiaPacific: Economic Potentials and Prospects. New Delhi: Continental Publishing House, 1988.

Cohen, stephen, ed. The Security of South Asia: American and Asian Perspectives. Urbana and Chicago: University of Illinois Press, 1987.

Dangol, B.D. SAARC Voyage From Dhaka to Bangalore. Kathmandu: Ministry of Education and Culture, Department of Archeology, 1987.

Deutsch, Karl, et al., eds. Political Community and the North Atlantic Area. Princeton, New Jersey: Princeton University Press, 1957.

Dharamdasani, M.D. South Asian Regional Cooperation: An Exercise in Open Diplomacy. Varanasi: Shalimar Publishing House, 1985. 
Etzioni, Amitai. Political Unification: A Comparative Study of Leaders and Forces. New York: Holt, Rhinehart and Winston, 1965.

Falk, Richard A. and Saul H. Mendlowitz. Regional Politics and World order. San Francisco: W.H. Freeman and Company, 1973.

Feld, Werner $J$. and Gavin Boyd, eds. Comparative Regional Systems: West and East Europe, North America, the Middle East and Developing Countries. New York: Pergamon Press, 1980.

From SARC to SAARC: Milestones in the Evolution of Regional Cooperation in South Asia $(1980-1988)$ : Volume I. Kathmandu: South Asian Association for Regional Cooperation, 1988.

Ganguly, sumit. The origins of War in South Asia. Boulder: Westview Press, 1986.

Ghosh, Partha S. Cooperation and Conflict in South Asia. New Delhi: Manohar Publications, 1989.

Haas, Ernst B. The Uniting of Europe. Stanford, California: Stanford University Press, 1958.

Kaplan, Morton. System and Process in International Politics. New York: John Wiley \& Sons, 1957.

Lieber, Robert J. Theory and World Politics. Cambridge, Massachusetts: Winthrop, 1972.

Maghroori, Ray and Bennett Ramberg. Globalism versus Realism: International Relations' Third Debate. Boulder: Westview Press Inc., 1982.

Mishra, Pramod Kumar. South Asia in International Politics. Delhi: UDH Publishers, 1984.

Mitrany, David. A Working Peace System. London: Royal Institute of International Affairs, 1946.

Mukherjee, T.B. Inter-State Relations in Ancient India. Meerut: Meenakshi Prakashan, 1967.

Muni, S.D and Anuradha Muni. Regional Cooperation in South Asia. New Delhi: National Publishing House, 1984 .

Peterson, Peter G. U.S.-Soviet Commercial Relations in a New Era. Washington D.C.: Department of Commerce, 1972 . 
Prasad, Bimal. Regional Cooperation in South Asia: Problems and Prospects. New Delhi: Vikas Publishing House, 1989.

Qureshi, M.L. Survey of Economic Resources and Prospects of South Asia. Colombo: Lotus Press Ltd., 1981.

Rahman, Atiur. Political Economy of SARC. Dhaka: University Press Ltd., 1985.

Satyamurthy, K., ed. South Asian Regional Cooperation. Hyderabad: Institute of Asian Studies, 1982.

Sen Gupta, Bhabani, ed. Regional Cooperation and Development in South Asia (Volume I): Perception, Military and Nuclear Arms. New Delhi: South Asian Publishers, 1986.

Thapar, Romila. A History of India: Volume I. Baltimore: Penguin Books, 1966.

Timmons, Thomas J. U.S. and Asia Statistical Handbook. Washington D.C.: Heritage Foundation, 1989.

Viner, Jacob. The Customs Union Issue. New York: Carnegie Endowment for International Peace, 1950.

Wheare, K.C. Federal Government. London: Oxford University Press, 1953.

\section{ARTICLE8}

Ahmad, Naveed. "Recent Developments in Indian Foreign Policy." Pakistan Horizon Vol. 33, No. 3 (1980): 47-95.

Ali, Salamat. "A Hint of Hope." Far Eastern Economic Review, 12 January $1989,11$. - "In ASEAN's Footsteps." Far Eastern Economic Review, 5 December 1985, 44. - "Smoothed-over Summit." Far Eastern Economic Review, 19 November $1987,47$.

Review, 27 November 1986,30 .

Ayoob, Mohammed. "The Primacy of the Political: South Asian Regional Cooperation (SARC) in Comparative Perspective." Asian Survey Vol. 25, No. 4 (April 1985): 443-457. 
Banskota, N.P. "Nepal: Towards Regional Economic Cooperation in South Asia." Asian Survey Vol. 21, No. 3 (March 1981): 342-354.

Baral, Lok Raj. "Nepal's Security Policy and South Asian Regionalism." Asian Survey Vol. 26, No. 11 (November 1986) : 1207-1219.

Baruah, Sanjib. "Immigration, Ethnic Conflict and Political Turmoil: Assam 1979-1985." Asian Survey Vol. 26, No. 11 (November 1986): 1184-1206.

Bobb, Dilip. "South Asia: Sphere of Suspicion." India Today, 15 December 1983, 63.

and Srinivas Prasad. "SAARC: Painful Progress." India Today, 15 December $1986,65$.

Bokhari, Imtiaz. "South Asian Regional Cooperation: Progress, Problem, Potential and Prospects." Asian Survey Vol. 25, No. 4 (April 1985): 371-390.

Clad, James. "India: A World at War with Itself." The Washington Post, 31 March 1991, B3.

Crossett, Barbara. "South Asian Leaders Call For Efforts Against Drugs." The New York Times, 25 November 1990, p 21 (L).

- "South Asian Nations In Turmoil will Meet." The New York Times, 21 November 1990, p A7 (L).

Facts on File, Vol. 45, No. 2352 (20 December 1985), 947.

Gupta, Aniruddha. "India-Nepal Discord." Economic and Political Weekly, 22 April 1989), 853.

Gupta, Shekhar. "Benazir's Acid Test." India Today, 15 July $1989,76$.

- "Fourth SAARC Summit: Coming of Age." India Today, 31 January 1989, 26.

and Mushahid Hussain. "Benazir Under Seige." India Today, 31 August 1990, 15.

Haas, Ernst B. "The Study of Regional Integration: Reflections on the Joy and Anguish of Pre-Theorizing." International organization Vol. 24, No. 4 (Autumn 1970): 607-648. 
- "Turbulent Fields and the Theory of Regional Integration." International organization Vol. 30, No.4 (Spring 1976): 173-212.

Islam, M. Rafiqul. "The Ganges Water Dispute: An Appraisal of a Third Party Settlement." Asian Survey Vol. 27, No. 8 (August 1987): 918-934.

Jain, Madhu. "An Idyllic Friendship." India Today, 15 February $1990,11$. 1990,41 .

Kadeeer, Ahmed A. "The Concept of Non-Alignment and Its Impact on South Asia." Pakistan Horizon Vol. 34 , No. 3 (1981): 36-45.

Keesing's Contemporary Archives, Vol. 32, No. 3 (March 1986), 34243 .

$1986), 34815$.

, Vol. 32, No.12 (December

Keesing's Record of World Events, Vol. 33, No. 12 (December 1987), 35614.

$1989), 36485$. , Vol. 35, No. 2 (February $1990), 37357$ Vol. 36, No. 3 (March

Khilnani, Nirijan K. "India's Political and Economic Policies Towards Her Neighbors." Round Table Vol. 301 (January 1987): 53-58.

Menon, K.T.R. "Indo-Pak Talks from December 18." The Times of India, 23 November 1990, 7 .

Mishra, Pramod Kumar. "Towards A Framework of South Asian Regional Cooperation: Colombo to Kathmandu." Foreign Affairs Report Vol. 21, No. 12 (December 1982): 213231.

Muni, S.D. "India and Regionalism in South Asia: A Political Perspective." International studies Vol. 17, No. 3-4 (July-December 1978): 483-501. 
- "India's Political Preference in South Asia: A study in India's Responses to systemic Changes in the Region." India Quarterly Vol. 31, No. 1 (January-March 1976): 23-35.

- SARC: Building Regionalism from Below." Asian Survey Vol. 25, No. 4 (April 1985): 391-404.

Namboodiri, P.K.S. "India and Bangladesh: A New Beginning." Strategic Analysis Vol. 6, No. 8 (November 1982): 459462 .

Naqvi, M.B. "South Asian Cooperation." Pakistan Horizon Vol. 36 , No. 3 (1983): 21-36.

Noorani, A.G. "The Kashmir Question." India Today, 30 December 1990,61 .

Prasad, Srinivas. "SAARC: Painful Progress." India Today, 15 December 1986,15 .

Rahman, Habibur. "Whose is South Talpatty Island?" Asian Survey Vol. 15, No. 5 (October 1987): 437-444.

Rahman, Syedur. "Issues and Agenda for South Asian Regional Cooperation: A Bangladeshi Perspective." Asian Survey Vol. 25, No. 4 (April 1985): 405-425.

Rana, A.P. "Regionalism as an Approach to International Order: A Conceptual Overview." International studies Vol. 18, No. 4 (October-December 1979): 491-523.

Rao, P. Venkateshwar. "Ethnic Conflict in Sri Lanka." Asian Survey Vol. 38, No. 4 (April 1988): 419-436.

Rao, R.V.R. Chanderasekhara. "Regional Cooperation in South Asia." Round Table 293 (January 1985): 53-65.

Ray, Ashwini K. "Pakistan's Post-Colonial Democracy: Implications for Indo-Pakistani Relations." Economic and Political Weekly, 22 April 1989, 867.

Richter, William L. "Mrs. Gandhi's Neighborhood: Indian Foreign Policy Toward Neighboring Countries." Journal of Asian and African Studies Vol. 22, No. 3-4 (1987): 250-265.

"SAARC Summit: Islamabad Declaration." strategic Digest Vol. 19, No. 2 (February 1989): 56-64.

Singh, Raminder. "Breaking the Ice." India Today, 15 July $1989,79$. 
"Gang-Up on Big Brother." India Today, 30 November $1987,33$.

- "The Seige of Dhaka." India Today, 15

December 1987, 69.

"Towards Estrangement." India Today, 30 April 1989, 70 .

"South Asia: The Spirit of SAARC." Round Table Vol. 301 (January 1987): 2-6.

Tempest, Ron. "7 South Asian Nations Vow Joint Action on Terrorists." Los Angeles Times, 6 November 1987, 13.

Vaitsos, Constantine. "Crisis in Regional Economic Cooperation (Integration) Among Developing Countries: A Survey." World Development Vol. 6 (June 1978): 719-769. 
VITA

\section{PAPIA GUHA}

Born in Calcutta, India, July 18, 1966. Graduated from Loreto House, Calcutta, July 1985. B.A. (Honors), st. Xavier's College, Calcutta University, 1988. M.A. candidate, The College of William and Mary in Virginia, 1991. All requirements for this degree have been completed, including the thesis: Regional Cooperation in South Asia. 